\title{
Judge Charles E. Clark and The Federal Rules of Civil Procedure*
}

\author{
Michael E. Smith ${ }^{\dagger}$
}

Insofar as we suppose that judicial decisions are attributable to the prior social experiences and attitudes of judges, we are tempted to predict the outcome when a judge is called upon to pass on his own work as scholar and legislator. The reforms for which he has fought will tend to dominate his viewpoint to the exclusion of competing considerations. If their validity is challenged under the Constitution or other governing law, he will defend them zealously. Should another court, even a higher one, construe them in ways he dislikes, he will do his best to avoid the precedents. If the statutory language of the reforms or the understandings on which they were enacted are themselves at variance with his preferences in certain particulars, he will seek to cure the discrepancies through judicial interpretation.?

* Copyright 1976 by Michael E. Smith. I am grateful to the William Nelson Cromwell Foundation, which is generously supporting my research on the history of the Second Circuit; to Professor Elias Clark and the Yale Law School, for allowing me to examine Judge Clark's private papers and for facilitating their use; and to Profesors Charles Alan Wright of the University of Texas and Jan Vetter of the University of California at Berkeley, whose advice has saved me from the worst of my mistakes. Professor Wright, coauthor of a definitive treatise on the Federal Rules, 4-12 C. Wright \& A. Militer, Federal Practice and Procedure (1969-1973), was Clark's law clerk and later his clief adviser on the 1955 proposed amendments to the Rules.

+ Professor of Law, University of California at Berkeley.

1. Professor Kadish suggests that Felix Frankfurter, perhaps the best known scholarlegislator-judge, bore out these predictions. In the late 1920's, Professor Frankfurter coauthored a classic study, F. Frankfurter \& N. Greene, The Labor Injunction (1930), which detailed the abuses of the injunction, both procedural and substantive, and recommended that it be abolished as a weapon against unionization. At the same time, he helped draft the Norris-LaGuardia Act, ch. 90, 47 Stat. 70 (codified at 29 U.S.C. $\$ \$ 101.110$, 113-115 (1970)), finally adopted in 1932, which carried out the book's legislative proposals. In the course of drafting the law, Frankfurter and his colleague, Senator George Norris, were urged to ban not only injunctions but all other legal proceedings in the federal courts against the specified labor activities. Although sympathetic to the plea, they ultimately rejected it, mainly for fear that enlargement would expose the bill to constitutional assault. By the time Frankfurter was appointed to the Supreme Court in 1939, that tribunal had dispelled the constitutional doubts. Thus, when he was confronted in United States v. Hutcheson, 312 U.S. 219 (1941), with a criminal prosecution against labor union officers under the Sherman Act, Kadish suggests that he found irresistible the temptation to hold that the Norris-LaGuardia Act had indirectly precluded legal reprisals of any kind against the activities covered by the statutc. See Kadish, Labor and the Law, in Felix Frinkfurter: The Judge 164 (WV. Mendelson ed. 1964). Kadish concludes: "Maintaining the equipoise between adjudication and legislation, difficult as it is, proved impossible here, where the judge had also, in effect, bcen the legislator." Id. at 173 . 
Probably the fullest and most complex example of the scholar and legislator turned judge is Charles E. Clark. After nearly 15 years at the Yale Law School spent teaching and writing on civil procedure, Clark was appointed Reporter to the Supreme Court's Advisory Committee on Rules for Civil Procedure. In that role he was principally responsible for the drafting of the Federal Rules, which became law in 1938. When the Committee was revived in 1942 to oversee the functioning of the Rules, Clark was reappointed its Reporter and held this job until 1956, when the Committee was discharged. During this period he was again largely responsible for the Committee's work, which included guiding a set of amendments to adoption in 1946 and proposing an even more far-reaching revision in 1955. In 1960 the Committee was reconstituted as part of the Judicial Conference of the United States, and Clark was again made a member. In the next three years until his death, many of the amendments he had urged in 1955 were finally adopted into law.

Meanwhile, in 1939 Clark had become a judge of the United States Court of Appeals for the Second Circuit. From that year until 1963, Clark heard hundreds of cases that required interpretation or application of the Federal Rules. In well over 100, he wrote signed opinions, dealing at length with more than 30 different Rules.

Previous research has emphasized the impact of Clark's scholarly and legislative experiences on his conduct as a judge. According to Marvin Schick, author of Learned Hand's Court, Clark's prior activities "significantly influenced his performance on the bench and limited his ability to creatively confront litigation which presented procedural questions." "' His work as a judge was characterized by "fierce, unrelenting promotion of fidelity to certain ideas that he had regarding procedure" and by a "passion and fervent devotion to the rules and the work of the Advisory Committee." 3 As a consequence, "for the most part, Judge Clark rigorously defended procedural rules irrespective of results." 4

The purpose of this article is to probe more intensively and completely the proposition that in cases involving the Federal Rules Clark's behavior was strongly influenced by his experience as scholar and draftsman of the Rules. My examination of these cases confirms this proposition, with two especially significant qualifications. First, the extent to which Clark stood rigidly by his prior procedural views can be explained in part by his particular personality. Second, on

2. M. Schick, Learned Hand's Court 31 (1970).

3. Id. at 32,241 .

4. Id. at 225 . 
a number of subjects Clark had to make hard choices, unaided by his prior views, with results that could not easily have been predicted.

In Part I of the article, I discuss the main views Clark brought with him to the bench concerning the Rules. A series of succeeding sections deals with his judicial work on each of these subjects. For efficiency, I have confined myself largely to litigated cases in which Clark wrote signed opinions dealing expressly with the Rules. ${ }^{5}$ The article ends with an attempt to assess the data in terms of the problem posed above.

\section{Clark's Prior Views}

Discussion of the views Judge Clark brought with him to the bench may aptly begin with a lecture entitled Procedure: the Handmaid of Justice, ${ }^{6}$ published shortly before he became a judge, in which he summed up his beliefs on the subject. Clark implicitly urged two of the cardinal virtues of this concept of procedure: cases would be decided on their merits rather than by procedural rulings, and this would occur with an economy of time and resources. He never analyzed systematically the potential clash of these values in particular cases, but was much more interested in working out their implications for lawmaking. These he deemed to be merger of law and equity in "a single civil action," "general as distinguished from special pleading," and "freedom to join diverse claims and various parties." $"$ Virtually all Clark's procedural reforms derive from these specific policies or their underlying values.

The first plank of Clark's reform platform was the merger of law and equity prescribed in Rule $2 .^{8}$ The only major procedural dis-

5. This excludes not only Clark's per curiam opinions, opinions written by others with his advice, and opinions in which issues involving the Federal Rules were passed over in silence, but also his activities as a judicial administrator. Within these bounds, I have aimed for relatively thorough treatment in part to provide raw material for readers with related but broader interests.

I have relied mainly on traditional materials: Clark's judicial opinions, published writings, and recorded speeches and the legal analyses of other scholars. But I have also had access to Clark's private correspondence, the recollections of personal acquaintances, and the memoranda exchanged among the judges of the Second Circuit on each of the cases discussed herein. The last are a particularly informative source, but also a highly sensitive one by traditional standards of the profession. I have declined to quote the memoranda for what seemed only to be purposes of entertainment; $I$ have not spared them when I felt they might illuminate the subject.

6. Clark, Procedure: The Handmaid of Justice, 23 Wash. U. L.Q. 297 (1938) [hereinafter cited as Clark, Handmaid].

7. Id. at 308 .

8. The Federal Rules of Civil Procedure have been amended many times since their passage in 1938. Unless otherwise noted, when the Rule discussed in the text may be understood by reference to the present Rules, citation is to the present form. When confusion would result, citation is to the earlier form of the Rule. 
tinction which Clark felt ought to survive merger concerned the right to jury trial. On this point his main objective was to prevent losing parties from manipulating the troublesome boundary between law and equity to obtain reconsideration..$^{9}$ Accordingly, Rule 38 provided for a waiver of jury trial if it was not claimed explicitly at the start of the proceeding. Indeed, Clark would have gone further to ensure against appellate reversal, allowing the judge to order jury trial in all cases regardless of the parties' rights. ${ }^{10}$ This scheme, included in a preliminary draft of the Rules, ${ }^{11}$ was one of several provisions eventually rejected by the Advisory Committee after consultation with lawyers, scholars, and judges. As for the right to a jury trial, Clark contended that it ought to depend on the status of the action at the time the Constitution was written, and that it should be determined as to each claim presented rather than by characterizing the action as a whole. ${ }^{12} \mathrm{He}$ did not notice the potential conflict between these two approaches when the historical rule was to treat the entire action as equitable notwithstanding the presence of legal claims. ${ }^{13}$

The second feature of Clark's reform platform was "general as distinguished from special pleading:" He believed that a great variety of pleading techniques should be permitted. ${ }^{14}$ He definitely preferred, however, that the pleading present facts alone, rather than legal theories as well, and that the facts be stated in a brief, general fashion. ${ }^{15}$ In this respect Clark was again prepared to go further than the Advisory Committee, ${ }^{16}$ but his views were adequately provided for in Rules $8(\mathrm{a})(2)$ and $10(\mathrm{~b}) .^{17}$

At the same time, Clark insisted that there were limits to the generality of pleading allowed under the Federal Rules. A bare allegation that the defendant had injured the plaintiff through negli-

9. Clark \& Moore, A Net' Federal Civil Procedure II, 44 YALE L.J. 1291, 1297-98 (1935).

10. Proceedings of $1 \mathrm{HL}$ AB. INstitute on the filderal Rules of Civil Procedure, Clevel.ind, OHo 228 (1938) [hercinafter citcd as 1938 Cleveland Proclidings].

11. Untred States Supreate Court, Auvisony Commitice on Rulcs for Civil Procedure, Preliminary Draft of Rules of Civil procedure for the District Courts of the United States and the Supreme Coukt of thic Districr of Columbia 83 (1936) [hereinafter cited as 1936 Preliminaky Drafr].

12. Clark \& Moore, supra note 9, at 1296.

13. See 1938 Cleveland Proceedixgs, supra note 10, at 274-76.

14. See id. at 228.

15. Clark, Handmaid, supra note 6 , at 316 .

16. 1938 Cleveland Proceedings, supra note 10, at 220.

17. Rule $8(a)$ requires that a pleading contain a short and plain statement of the basis for the court's jurisdiction, a short and plain statement of the claim, and a demand for judgment. Rule 10 (b) requires separate statements only for claims based upon separate transactions or occurrences and only when separation would facilitate clarity of presentation. 
gence, he said, would not suffice. ${ }^{18}$ But if such an error in pleading were made, Clark sought to minimize its procedural consequences. He supported liberal amendment of defective pleadings, as provided in Rule 15, and also endorsed Rule 54(c), which made amendment of defective demands for relief unnecessary. ${ }^{19}$

Intimately related to pleading, in Clark's view, was pretrial practice, by which facts were exposed, issues narrowed, and some cases disposed of without trial. Clark opposed the traditional methods of achieving these objectives, deeming them both harsh and inefficient. ${ }^{20}$ He succeeded in abolishing demurrers by Rule 7(c), in partially consolidating dilatory pleas ${ }^{21}$ in Rule 12 , and in obtaining discretion for the judge to postpone hearing them until trial. He would also have abolished the bill of particulars, ${ }^{22}$ obliged the dilatory pleas to be asserted with the answer on the merits, and, except under unusual circumstances, required them to be heard at trial..$^{23}$ The preliminary draft largely achieved his aims, ${ }^{24}$ but after receiving the reactions of bench and bar, the Advisory Committee permitted the traditional procedures to survive.

As better means of achieving his pretrial objectives, Clark supported the pretrial conferences of Rule 16, the depositions and discovery provided for by Rules 26-37, and the motions for summary judgment of Rule 56..$^{25}$ Except for the last, Clark knew little about these provisions; another scholar, Professor Edson Sutherland, had drafted them. But Clark saw them as important complements to his campaign for simplified pleading and against traditional pretrial practices. As for summary judgment, Clark would have made it a more useful means of testing the merits of a case prior to trial by requiring

18. Proceedings of the ABA Srmposium on the federal Rules of Civil Procedure, New YORK 241 (1938) [hereinafter cited as 1938 New YORK Proceedings].

19. Clark \& Moore, supra note 9, at 1300, 1303. Rule 54(c) provides: "Except as to a party against whom a judgment is entered by default, every final judgment shall grant the relief to which the party in whose favor it is rendered is entitled, even if the party has not demanded such relief in his pleadings."

20. Clark \& Moore, supra note 9 , at 1308 . He felt that traditional pretrial methods such as demurrers and dilatory pleas, see note 21 infra, postponed actual decisions on the merits and unduly penalized parties who made formal errors. Clark \& Moore, supra note 9 , at $1299-1306$.

21. Dilatory pleas are a class of defenses not related to the merits of the case. At common law, they consisted of pleas to the personal or subject matter jurisdiction of the court and pleas in abatement alleging incapacity to ste, misjoinder of parties, im. proper service of process, and similar procedural defects. C. Clakk, Conr Pleidinc 500-01 (2d ed. 1947).

22. Clark \& Moore, supra note 9 , at $\mathbf{1 3 1 0 .}$

23. 1938 Cleveland Proceedings, supra note 10, at 239.

24. 1936 Prelminary Draft, supra note 11, at 29-30.

25. Clark, Fundamental Changes Effected by the New Federal Rules, 15 TrN. L. REv. 551, 567, 580 (1939). 
the answering party to respond with factual allegations as specific as those supporting the motion. ${ }^{26}$ The preliminary draft came closer to achieving this objective than the final version of the Rules.27

The third aspect of Clark's procedural platform was "freedom to join diverse claims and various parties," enabling entire disputes to be resolved in one proceeding. With his strong support, ${ }^{28}$ Rule 13 and numerous succeeding provisions permitted the parties to opt for exceedingly wide joinder. Clark hoped to avoid possible constitutional or statutory limitations by means of ancillary jurisdiction over all parts of the suit arising out of the same facts. ${ }^{29}$ Indeed, as in Rule 13(a), he approved of compelling the parties to join all claims connected factually with the original action. ${ }^{30}$

Clark also endorsed simplified selection of proper parties. Although Rule 17(a), over his objections, ${ }^{31}$ retained the traditionally complex concept of "the real party in interest," Clark insisted that the Advisory Committee understood this to mean merely the person to whom substantive law had already given the right to sue. ${ }^{32}$ And in the event of an error, or a change in circumstances, Clark favored the free substitution of parties provided by Rules 21 and $25 .^{33}$

There were limits to Clark's endorsement of joinder, however. $\mathrm{He}$ suggested that judgments in so-called "spurious" class actions ought to bind only actual participants, ${ }^{34}$ although this restriction was not spelled out in Rule 23(a)(3). ${ }^{35}$ He also felt that Rule 14 went too far in allowing a defendant to implead a party liable solely to the plaintiff, ${ }^{3 b}$ apparently believing that the plaintiff would be forced to include the impleaded party in his suit. This provision, omitted from the preliminary draft, was added later at the behest of the admiralty bar. ${ }^{37}$

26. Clark, The Proposed Rules of Civil Procedure, 22 A.B.A.J. 447, 450 (1936) [hereinafter cited as Clark, Proposed Rules].

27. 1936 Preliminary Draft, supra note 11, at 76-77. The 1963 amendment to Rule $56(e)$ on summary judgment requires this specific response from the party opposing summary judgment. 6.2 Moore's Federal Practice [ 56.22[2], at 56-1335-46 (2d ed. 1975).

28. 1938 Cleveland Proceedincs, supra note 10, at 262.

29. Proceedings of the ABA Institute on the federal Rules of Civil procedure, Washington, D.C. 62 (1938) [hereinafter cited as 1938 W.ashington Proceedings].

30. Clark \& Moore, supra note 9, at 1306.

31. Clark, Proposed Rules, supra note 26, at 491.

32. 1938 Cleveland Procefdings, supra note 10, at 257.

33. Clark \& Moore, supra note 9, at 1317-18.

34. 1938 Cleveland Proceedings, su pra note 10, at 264-65.

35. FED. R. Crv. P. 23(a)(3) (1938). The modern Rule 23 differs significantly from the original version. For a discussion of the differences between original and amended Rule 23, see note 167 infra.

36. See Fed. R. Civ. P. 14 (1938). The Current Rule 14 allows this only in admiralty calses.

37. 1938 Washington Proceedings, supra note 29, at 61-62. 
Merger of law and equity, simplified pleading, and wide joinder of causes and parties were the main provisions of the original Federal Rules on which Clark later passed as a judge and on which he expressed strong personal views prior to his appointment. ${ }^{3 s}$ The Rules covered other matters that he had never pondered as a scholar, the framing of which he had left primarily to his colleagues, including Professor J.W. Moore, and on which he lacked strong personal opinions. Many concerned technical details which never arose in subsequent litigation, but on others Clark later ruled as a judge. The most controversial was Rule 54(b), which concerned piecemeal appeals. The preliminary draft had allowed such an appeal whenever any "issue" had been finally determined by a trial judge; 39 the enacted version cut this down greatly, in effect barring appeal until an entire "claim" had been finally adjudicated.

Thus, the heritage Clark brought with him to the bench from his years as scholar and lawmaker was more complex than we might have supposed. On many subjects he had well-developed scholarly views which he succeeded in writing into law. Here, his course as a judge was presumably clearly marked. But on other subjects on which he had strong views, he was outvoted by his colleagues on the Advisory Committee. There, he would have to choose whether to follow his own beliefs or the Rules. On yet other issues, Clark had no distinct views or only mild preferences. For these, he would be obliged to work out his perspective as cases arose after he became a judge.

Apart from his disappointment in the failure to enact several of his proposals, Clark felt that the Federal Rules constituted a thoroughly sound reform. He therefore endorsed their widest possible use. Although he never publicly attacked Rule $81(\mathrm{a})(\mathrm{l})$, which made the Rules inapplicable to admiralty cases, there is much reason to believe that he regretted this exclusion. ${ }^{40}$ And following the decision in Erie Railroad v. Tompkins, ${ }^{41}$ which came down during the final stage of

38. For Clark's views on the admissibility of evidence (Rule 43(a)), sce Clark, Proposed Rules, supra note 26, at 450; Clark, foreword: A Sympositum on the Uniform Rules of Evidence, 10 Rur. L. Rev. 479, 481-83 (1956). For his views on review of district court findings under Rule 52(a), see Clark, Proposed Rules, supra note 26, at 451; Clark, Review of Facts Under Proposed Federal Rules, 20 Jub. 129 (1936); Clark \& Stone, Ke: view of Findings of Fact, 4 U. CHI. L. REV. 190 (1937).

39. 1936 Preliminary Draft, supra note 11, at 109.

40. Letters to Alexander Holtzoff (Oept. 27, 1939) and Roscoe Hupper (Dec. 17, 1941). Unless otherwise noted, all letters are written by or to Charles Clark. All letters are in the Charles Clark Papers, Yale Law Library.

41. 304 U.S. 64 (1938). 
the adoption of the Rules, Clark indicated that he opposed displacement of the Rules by state law.:

\section{Clark's Judicial Record}

\section{A. Merger of Law and Equity}

To a considerable extent, Judge Clark's decisions on the merger of law and equity and the right to jury trial corresponded with his prior views. Thus, he invariably disparaged lingering conceptual distinctions between the two judicial systems. In the early case of Beaunit Mills, Inc. v. Eday Fabric Sales Corp. ${ }^{4 *}$ he held for the court that refusal to grant a jury trial was not appealable prior to final judgment. He did this in the face of a Supreme Court precedent which treated a similar interlocutory decision as an injunction, issued by an equity judge to stay an action at law, which could be appealed.4* Clark felt that there were grounds to distinguish the precedent, but he also believed that the theory underlying it had been rendered obsolete by the merger of law and equity, and he viewed Beaunit as an opportunity to say so. Judge Jerome Frank had reservations about rejecting a Supreme Court precedent, at least when unnecessary, but Clark overrode his objections, ${ }^{4 \overline{5}}$ and the opinion denounced the injunction theory. ${ }^{40}$

Clark's zeal to remove these distinctions was heightened by Frank's opinion in Bereslavsky $v$. Caffey ${ }^{47}$ for a panel of which Clark was not a member. In a brief digression, Frank insisted that law and equity had not been fully merged, and that their continued separation aided legal development. ${ }^{48}$ This dictum, and its popularity among commentators, enraged Clark. He ridiculed it both off the bench ${ }^{49}$ and in

42. 1938 Washington Procefdings, supra note 29, at 49. For Clark's view on the application of the Rules to actions by or against the United States, see id. at 50. For his forecast of the way in which the Rules would be administered, sce Clark, Handmaid, supra note 6.

43. 124 F.2d 563, 565 (2d Cir. 1942).

44. Enelow v. New York Life Ins. Co., 293 U.S. 379 (1935).

45. Memoranda in Beaunit Mills, Inc. v. Eday Fabric Sales Corp., 124 F.2d 563 (2d Cir. 1942) (Dec. $13 \& 31,1941$ ). For every case on which he sat, Clark wrote memoranda to his fellow judges. Each memorandum is cited to the decision which it accompanied and is contained in the case files of the Charles Clark Papers, Yale Law Library. Unless otherwise noted, all case memoranda were written by Clark.

46. 124 F.2d at 565-66.

47. 161 F.2d 499 (2d Cir.), cert. denied, 332 U.S. 770 (1947).

48. Id. at 500 .

49. Letter to Arthur Corbin (Dec. 2, 1952); Clark, Book Review, 97 U. PA. L. Rev. 917, 919 (1949). 
his opinion in Fanchon \& Marco, Inc. v. Paramount Pictures, Inc.5" There, a lower court relying on Bereslavsky had ruled that a stockholder's derivative action, traditionally an equitable proceeding, could not be used to obtain treble damages under the antitrust laws. In his opinion overturning this ruling, Clark managed both to narrow Bereslavsky and to criticize it as "nostalgic dicta."

So eager was Clark to promote the merger of law and equity that he sought to achieve as a judge reforms rejected by those who enacted the Rules. As Reporter, he had tried unsuccessfully to give judges the power to order trial by jury in all cases, ${ }^{52}$ a reform which would have reduced the need to make fine distinctions between law and equity. After allowing 25 years to pass, Clark revived this idea in a draft opinion in DeGioia $v$. United States Lines Co. ${ }^{53}$ rejecting a party's complaint that a jury trial had improperly been forced upon him. Judge Henry Friendly doubted the basis for the ruling and Clark retreated, relying on a narrower ground for the same result. ${ }^{.4}$ But he soon resurrected the point in Fitzgerald $v$. United States Lines Co., this time putting his views on record in a dissenting opinion. ${ }^{55}$

Not all the issues relating to merger and jury trial were so easy for Clark; some gave him sufficient difficulty that he eventually changed his viervs. One was mainly technical. In speeches shortly after adoption of the Rules, Clark contended that under the new regime certain "equity cases," once begun without a jury, would remain without one, even though legal relief also was sought. ${ }^{50}$ Since this was the established practice prior to merger, his position conformed to the historical test that he espoused. He apparently failed to notice, however, that it was in conflict with another of his basic principles of merger-that the right to a jury should be determined as to each claim for relief rather than by characterizing the action as a whole. In Beaunit he corrected this doctrinal discrepancy by rejecting the purely historical test, as had Professor Moore. (This, in turn, required him to decide how to adjudicate an issue which related to both equitable and legal claims. He again followed Moore's pre-

50. 202 F.2d 731 (2d Cir. 1953).

51. Id. at 734 .

52. P. 917 supra.

53. 304 F.2d 421 (2d Gir. 1962), rev'd on other grounds, 374 U.S. 16 (1963).

54. Memorandum in DeGioia v. United States Lines Co., 304 F.2d 421 (2d Cir. 1962) (June 6, 1962).

55. 306 F.2d 461, 475-78 (2d Cir. 1962), rev'd on other grounds, 374 U.S. 16 (1963). See also Ring v. Spina, 166 F.2d 546, 550 (2d Cir. 1948) (Clark, J.), cert. denicd, 358 U.S. 813 (1948) (jury trial not waived by mixing legal and equitable claims, because such a rule would resurrect "the ancient divisions now abolished").

56. 1938 Cleveland Proceedings, supra note 10 , at $275-76,327$. 
scription, making the "basic" nature of the issue decisive.) $)^{57}$

Another point on which Clark's perspective altered over time involved a more significant conflict among his values: would amendment of a complaint by shifting from equitable to legal relief start a new period in which to claim jury trial? Allowing this would emphasize the distinction between law and equity, but to disallow the new time limit would make the initial pleading unduly decisive. Accordingly, in the second edition of his text on Code Pleading, he proposed a moderate test of waiver based on the reasonable foreseeability that a jury issue might arise. ${ }^{5 s}$ Perhaps it was Judge Frank's opinion in Bereslavsky that pushed Clark to a more negative position. By the early 1950's he had decided that no amendment could revive the right to claim a jury trial unless the amended complaint dealt with an entirely different factual situation. He tried to write this doctrine into law, not only through a change in the Federal Rules, ${ }^{59}$ but also by an opinion for the court in Alcoa S.S. Co. v. Ryan. ${ }^{60}$ Both ventures failed. Judge (later Justice) Harlan insisted that Alcoa be decided on the modest ground that the suit had been at law from the start, ${ }^{11}$ and the Advisory Committee did not report his proposal to the Supreme Court. ${ }^{62}$

\section{B. Pleading}

By contrast, Judge Clark's record on pleading consisted of virtually unremitting pursuit of his aims as a scholar and draftsman of the Rules. He continued to insist that a well-drafted complaint need contain only a concise general statement of the pertinent facts; it need not include either factual details or legal theories. He asserted these views in widely distributed writings, in lectures to practitioners, as Reporter to the Advisory Committee ${ }^{63}$ and in his judicial decisions. ${ }^{64}$

57. 124 F.2d at 565-66.

58. C. Clark, Code Pleading 117-20 (2d ed. 1947).

59. United States Supreme Court, Advisory Commitree on Rules for Civil Procedure, Preliminary Draft of Proposed Amendments to Rules of Civil Procedure for tile United States District Courts 39-40 (1954) [hereinafter cited as 1954 PreLIMINARY DRAFT].

60. 211 F.2d 576 (2d Cir. 1954).

61. Memoranda from Judge Harlan in Alcoa S.S. Co. v. Ryan, 211 F.2d 576 (2d Cir. 1954) (Mar. 9 \& 17, 1954).

62. The 1955 Advisory Committee recommendations did not contain Clark's proposal. United States Supreme Court, Advisory Committee on Rules for Civil Procedure, Report of Proposed Amendients to the Rules of Civil Procedure for the United States District Courts (1955) [hereinafter cited as 1955 RePorT].

63. E.g., id. at 18-19; Clark, Simplified Pleading, 2 F.R.D. 456 (1943).

64. E.g., Gins v. Mauser Plumbing Supply Co., 148 F.2d 974 (2d Cir. 1948); Lewis v. Vendome Bags, Inc., 108 F.2d 16, 18 (2d Cir. 1939) (Clark, J., dissenting), cert. denied, 309 U.S. 660 (1940). 
His most famous opinion on this subject was Dioguardi v. Durning, ${ }^{65}$ in which the court reversed dismissal of a complaint by a person of limited literacy who refused legal assistance. It found sufficient allegations that the Collector of Customs "sold my merchandise to another bidder with my price of $\$ 110$, and not his price of $\$ 120, "$ and that "three weeks before the sale, two cases, of 19 bottles each case, disappeared." was surprisingly terse and bland. Indeed, he deliberately abstained from expressing his views at length, explaining that "I have done too much preaching already," 67 and, at Judge Thomas Swan's request, he removed one of the few caustic lines in his draft opinion, a criticism of the United States Attorney for quoting the terms of the Field Code $^{68}$ rather than the Federal Rules. ${ }^{69}$ Nor was the holding itself particularly remarkable; it was joined by Swan and Augustus Hand, two especially level-headed judges.

Both in subject matter and in breadth of discussion, Clark's opinion in Nagler v. Admiral Corp. ${ }^{70}$ was much more significant. In the latter half of the 1950's, certain judges of the Southern District of New York, encouraged by defense counsel, began a campaign for greater precision in antitrust complaints. 'Clark saw this as a serious threat, not only to his long-maintained stand against special pleading, but also to the vindication of antitrust claims, a policy he endorsed. Consequently, in speeches at institutes of judges and lawyers he sought to combat the trend. ${ }^{71}$ Nagler, in which an antitrust complaint had been dismissed for faulty pleading, gave Clark the additional opportunity of writing his views into law. Initially, the other judges on the panel, Harrie Chase and Carroll Hincks, voted that Hincks would write an opinion affirming dismissal. ${ }^{72}$ Hincks was a cautious and conscientious judge, however, and after pondering for nearly three months the arguments and citations Clark furnished him, he not only came over to Clark's side, with Chase following him, but also offered

65. 139 F.2d 774 (2d Cir. 1944).

66. Id. at 779 .

67. Memorandum in Dioguardi v. Durning, 139 F.2d 774 (2d Cir. 1944) (Dec. 28, 1943).

68. In general, Clark admired the Ficld Code, a code of civil procedure adopted by New York in 1848 and by many other states subsequently, but he regarded its pleading provisions as greatly inferior to those of the Federal Rules. See C. Clark, Code Pleadinc, 21-31, 225-45 (2d ed. 1947).

69. Memorandum in Dioguardi v. Durning, 139 F.2d Ti4 (2d Cir. 1941) (Dec. 31, 1943).

70. 248 F.2d 319 (2d Cir. 1957).

71. Clark, Comment on Judge Dau'son's Paper on the Place of the Pleading in a Proper Definition of the Issues in the "Big Case," 23 F.R.D. 435 (1958); Clark, Special Pleading in the "Big Case," 2I F.R.D. 45 (1957).

72. Letter to Judge Alfred P. Murrah (July 22, 1957). 
the opinion to Clark. ${ }^{73}$ After disposing of the case itself in one paragraph, Clark observed that "because of their practical importance in routine litigation, we think some elaboration of both the pleading and the joinder issues is desirable," and then wrote four pages detailing his views on pleading. ${ }^{7+}$ Clark later expressed satisfaction that this decision had at least temporarily halted the campaign for special pleading in antitrust cases. ${ }^{\text {To }}$

This should not suggest that for Clark any pleading was sufficient. From the time the Federal Rules were adopted, he had asserted that there were limits to the generality of allegation they allowed. ${ }^{i 6} \mathrm{He}$ enforced this warning for the first time in 1950 in Anderson $v$. United States, ${ }^{77}$ a First Circuit case on which he sat as a visiting judge. ${ }^{\text {Ts }}$ In a counterclaim against the Government, a delinquent debtor complained of "demands ... for bribes, blackmail and the falsification of records, as more fully set forth in the defendant's request . . . for presentation of the evidence to the grand jury."' Clark ruled that this allegation was too incoherent to satisfy Rule $8(\mathrm{a})(2) .{ }^{\mathrm{so}}$

At least rhetorically, Clark asserted these limits on simplified pleading with increasing rigor as the 1950 's progressed. In the 1955 report of the Advisory Committee, he repeatedly insisted that the Federal Rules required the pleading of actual events and circumstances. ${ }^{81}$ One year later, in United States $v$. Lamont, , $^{\text {s" }}$ he issued a dictum against "a formalism of generality" that confuses "general pleadings with entire absence of statement of claim." Periodically thereafter, indeed in Nagler itself, $\$ 3$ he denounced the "notice theory of pleading" as alien to the Rules. ${ }^{s+}$

This evidence suggests that Clark became stricter about pleading as he grew older. But his sterner tone may have signified a tactical shift rather than a change of heart. In the 1950's Clark faced a serious assault on Rule 8(a), not only from those who sought precise

73. Memorandum in Nagler v. Admiral Corp., 248 F.2d 319 (2d Cir. 195\%) (Sept. 6, 1957).

74. 248 F.2d at $322,323-26$.

75. Letter to Julius Abeson (Oct. 14, 1957).

76. See pp. 917-18 supra.

77. 182 F.2d 296 (1st Cir. 1950).

78. Clark may have felt freer to sign a restrictive pleading opinion in a foreign jurisdiction.

79. 182 F.2d at 297 n.2.

80. Id. at 297 .

81. 1955 RePoRr, supra note 62 , at 19.

82. 236 F.2d 312, 317 (2d Cir. 1956).

83. 248 F.2d at 324 .

84. E.g., Clark, Two Decades of the Federal Civil Rules, 58 Colva. L. Rev. 435, 450 n.68 (1958). 
pleading in antitrust cases, but also from a group of California judges and lawyers who proposed restoration of the more demanding Field Code formulation in all cases. ${ }^{85}$ Clark may have decided to fend off these challenges by deemphasizing the liberality of existing law. After Anderson, he never again carried through on his harsh language by actually ordering a complaint dismissed for loose pleading.

Clark also persisted in his prior view that the penalties for erroneous pleading ought to be minimized. He repeatedly read Rule 15 to allow amendment of pleadings without any adverse consequences to the pleader. ${ }^{86}$ When remedies alone were at issue, he invariably cited Rule 54 (c) to the effect that even formal amendment of pleadings was unnecessary. ${ }^{87}$ When neither of these Rules was available, Clark sometimes simply recharacterized the prior proceedings to make them sufficient from the outset. ${ }^{88}$

The flavor of Clark's approach is conveyed by Truth Seeker Co. $v$. Durning ${ }^{89}$ which he later used in his casebook on pleading to illustrate the operation of Rule 54(c). ${ }^{\text {a }}$ A customs office had seized an incoming shipment of atheistic literature. The owner sued for delivery of the material, but since the office soon complied with this request the district court dismissed the action as moot. The plaintiff appealed solely in order to obtain costs. Not only did Clark assent to that request, but, his civil libertarian instincts ${ }^{91}$ apparently aroused, he contended that the district court also should have granted damages, ${ }^{02}$ though the plaintiff had never sought them at any stage of the case. He found that the boilerplate request in the complaint for "such other and further relief" was sufficient and furthermore that Rule 54(c) made a more explicit demand unnecessary. ${ }^{93}$ Clark persuaded a doubtful Judge Frank to join him, ${ }^{94}$ but Judge Chase dissented.

Most of these cases turned on their facts, but Technical Tape Corp. v. Minnesota Mining \& $M f g$. $\mathrm{Co}^{95}$ raised a general issue. The district

85. Clark, "Clarifying" Amendments to the Federal Civil Rules?, 14 Oню ST. L.J. 241, 245 (1953) [hereinafter cited as Clark, "Clarifying" Amendments].

86. E.g., SEC v. Rapp, 304 F.2d 786, 790 (2d Cir. 1962); Vernon Lumber Corp. v. Harcen Constr. Co., 155 F.2d 348, 349 (2d Cir. 1946).

87. E.g., Massachusetts Bonding \&. Ins. Co. v. New York, 259 F.2d 33, 40 (2d Cir., 1958); Matarese v. Moore-NicCormack Lines, Inc., 158 F.2d 631, 633 (2d Cir. 1946).

88. E.g., Pettus v. Grace Line, Inc., 305 F.2d 151, 155-56 (2d Cir. 1962) (Clark, J., dissenting); Rashap v. Brownell, 229 F.2d 193, 194-95 (2d Cir. 1956).

89. 147 F.2d 54 (2d Cir. 1945).

90. C. Clark, Cases on Modern Pleading 56-59 (1952).

91. See Schick, supra note 2, at 277-90.

92. 147 F.2d at 56 .

93. Id.

94. Memorandum of Judge Frank in Truth Seeker Co. v. Durning, 147 F.2d 54 (2d Cir. 1945) (Dec. 18, 1944).

95. 200 F.2d 876 (2d Cir. 1952). 
judge had dismissed the complaint for failure to allege a concrete controversy and had refused to allow the allegations to be supplemented under Rule 15(d), citing a prior Second Circuit holding that a defective complaint could not be supplemented. On appeal, the majority reversed on the ground that the original complaint had been adequate, ${ }^{90}$ but Clark was far too offended by this gloss on the Rules to let the issue pass. In a concurring opinion, he denounced the holding that a defective complaint might not be supplemented and dismissed the Second Circuit precedent as poorly considered. ${ }^{97} \mathrm{He}$ later persuaded the Advisory Committee to propose an amendment to the Rules supporting his position, ${ }^{9 s}$ one of the 1955 proposals that was shelved by the Supreme Court but subsequently adopted in $1963 .{ }^{09}$

\section{Pretrial Practice}

Pretrial practice is another subject on which Judge Clark almost invariably pursued views developed prior to his appointment. Indeed, so strong were these views that at times he adhered to them even when they conflicted with the Rules themselves. The pattern was most apparent in cases in which the facts were arguably irrelevant or not in dispute. Clark repeatedly insisted that trials be dispensed with in such cases and advocated the use of Rule 56 summary judgment for this purpose rather than the devices found in Rule 12, which involved judgment on the pleadings or dismissal for failure to state a claim.

The pattern appeared first in cases dealing with the relationship between Rules 12 and 56 . When the Rules were drafted, Clark had urged unsuccessfully that all pretrial motions be heard at the same time, when the facts were fully available. Once the Rules went into effect, he adopted the even more ambitious objective of equating Rule 12 to Rule 56 or abolishing Rule 12 altogether. He pursued these aims on the bench as well as in published writings and through the Advisory Committee. ${ }^{100}$ In a series of decisions he tried to establish that if affidavits were available a motion ought not to be

96. Id. at 878 .

97. Id. at 879 .

98. 1955 REPORT, supra note 62 , at 22-23.

99. 3 Moorr's Federal Practice 7 15.16[2], at 1085-87 (2d ed. 1975); p. 928 infra. For a case in which Clark did not allow a complaint to be supplemented, see United States v. Wissahickon Tool WWorks, 200 F.2d 996 (2d Cir. 1952).

100. Clark, Experience Under the Amendments to the Federal Rules of Civil Procedure, 8 F.R.D. 497, 500-01 (1949) [hereinafter cited as Clark, Experience Under the Amendments]; Clark, Simplified Pleading, 2 F.R.D. 456, 471-72 (1943). 
decided on the pleadings alone, that affidavits could be used whether the motion was under Rule 12 or Rule 56 , and that if both motions were made they ought to be considered together. ${ }^{101}$

None of these cases was more important than one on which he did not sit. Shortly after Judge Frank joined the court in 1941, he asked Clark's reaction to a conference memorandum Frank was writing which argued that affidavits could not be used on a motion under Rule 12. Greatly distressed, Clark responded that such a ruling would restore the worst of the demurrer practice abolished by the Rules. When he received no answer, he wrote Frank again and asked for a chance to present his views to the other sitting judges. ${ }^{102}$ This proved unnecessary, for the subsequent opinion in Boro Hall Corp. v. General Motors Corp. ${ }^{103}$ written by Judge Augustus Hand, held explicitly that affidavits could be considered on a Rule 12 motion.

With these precedents Clark had largely achieved his purpose. Nevertheless, he sought to affirm his victory with a compromise amendment to Rule $12,{ }^{104}$ finally adopted in 1946 , providing that if affidavits were submitted on a motion under Rule 12(b)(6), it ought instead to be treated as a Rule 56 motion. ${ }^{105}$

A related reform that Clark resolved to complete as a judge was to ensure that motions going to the merits, whether under Rule 56 or Rule 12, would be granted liberally. As a draftsman of the Rules, Clark would have strengthened summary judgment by putting on the opposing party the burden of offering specific proofs rather than general allegations. ${ }^{106}$ Undaunted by his failure to obtain explicit language in Rule 56 to this effect, Clark inserted it in a series of opinions, headed by Engl v. Aetna Life Ins. Co. ${ }^{107}$ Not satisfied with these efforts, he also attempted again, in the 1955 amendments proposed by the Advisory Committee, to write his approach into the Rules. ${ }^{108}$ This proposal was finally enacted in $1963 . .^{100}$

101. E.g., Cohen v. American Window Glass Co., 126 F.2d 111 (2d Cir. 1942); Central Mexico Light \& Power Co. v. Munch, 116 F.2d 85 (2d Cir. 1940).

102. Letters from Judge Frank (Nov. $17 \&$ 25, 1941); letters to Judge Frank (Nov. $19 \& 24,1941)$.

103. 124 F.2d 822, 823 (2d Cir. 1942), cert. denied, 317 U.S. 695 (1943).

104. Clark, Simplified Pleading, 2 F.R.D. 456, 465-67 (1943).

105. Clark, Experience Under the Amendments, supra note 100, at 500-01; 2A Moore's

Federal Practice [1 12.01[7], at 2211-12 (2d ed. 1975).

106. Pp. 918-19 supra.

107. 139 F.2d 469 (2d Cir. 1943). For additional examples, see Rotberg v. Dodwell \& Co., 152 F.2d 100 (2d Cir. 1945); Nahtel Corp. v. West Virginia Pulp \& Paper Co., 141 F.2d 1 (2d Cir. 1944).

108. 1955 REPORT, supra note 62, at 56-59. For further exposition of his views, see Clark, "Clarifying" Amendmenls, supra note 85 , at 241 .

109. 6 Moore's Federal Practice If 56.01[13], at 56-21 (2d ed. 1975). 
The question of burden of proof was only one facet of the larger issue of how substantial a factual dispute would suffice to preclude summary judgment. In a series of divided decisions on this issue between 1944 and 1947, Clark invariably insisted that the motion be granted. Most of the cases involved copyright claims, of which he was innately skeptical, but the major issue for Clark was procedural. Indeed, he saw much of his reform program, including simplified pleading and abolition of the dilatory pleas, as dependent upon a liberal use of Rule $56 .{ }^{110}$ Unfortunately for Clark, Judges Learned Hand and Frank strongly opposed his views, and Judge Swan was his only ally. The result was a bitter battle within the Second Circuit.

The first case was MacDonald v. Du MIaurier, ${ }^{111}$ in which the defendant was accused of basing her renowned novel, Rebecca, on an obscure melodrama. Swan initially sided with Clark but later joined Learned Hand in opposition. ${ }^{112}$ The controversy within the panel actually concerned the merits of whether the similarities between the two novels were so great as to constitute improper use under copyright law, not whether this or any other issue could be decided only after a full trial. ${ }^{113}$ Yet in his dissenting opinion Clark wrote at considerable length as if summary judgment itself were at stake. ${ }^{114}$ Afterward, he privately characterized the majority position as highly dangerous. ${ }^{115}$

Next was Madeirense do Brasil $S / A$ v. Stulman-Emrick Lumber Co., ${ }^{110}$ a genuine summary judgment case. The panel disagreed over the question whether, in computing damages for breach of a contract to sell lumber, the district court correctly calculated the market value of the lumber on the motion papers alone. ${ }^{117}$ At first, Clark was so eager for a unanimous decision supporting the principle of summary judgment that he was willing to take the contract price of the lumber as its market value, eliminating recovery for the appellee on this element of the damages. Even when his bid for Judge Frank's vote failed, he was concerned that the decision be as acceptable as possible, and after conferring with Professor Moore, he suggested to Judge Swan that they allow the seller another opportunity to offer proof of

110. See Arnstein v. Porter, 154 F.2d 464, 475 (2d Cir. 1946) (Clark, J., dissenting); Clark, The Summary Judgment, 36 MinN. L. REv. 567, 578 (1952).

111. 144 F.2d 696 (2d Cir. 1944).

112. Memorandum of Judge Swan in MacDonald v. Du Maurier, 44 F.2d 696 (2d Cir. 1944) (June 14, 1944).

113. Id.

114. 144 F.2d at 701-03.

115. Letter to Judge Frank (May 4, 1945).

116. 147 F.2d 399 (2d Cir.), cert. denied, 325 U.S. 861 (1945).

117. Id. at $404 \cdot 07$. 
a different figure. Since Swan thought the concession unnecessary, ${ }^{118}$ the opinion came down as a simple affirmance.

Clark's campaign for liberal summary judgment suffered a severe setback less than four months later in Doehler Metal Furniture Co. v. United States, ${ }^{119}$ a case in which he did not sit. Judges Learned Hand and Frank combined with Judge Chase to deprecate summary judgment as a risky expedient. Not only did they hold against granting it when there was the "slightest doubt" about the facts; disparaged Madeirense itself in language that was toned down only after Clark complained to Hand about it..$^{121}$

Thus the stage was set for the confrontation between Clark and Judges Frank and Learned Hand in Arnstein v. Porter. ${ }^{122}$ An eccentric old composer had brought another in a long series of plagiarism suits, this time charging that Cole Porter had stolen from him bits of such tunes as Begin the Beguine and Night and Day. One issue was whether the plaintiff, who had failed to extract an admission of copying from the defendant by deposition and whose own evidence on that issue lacked any credibility, should have another chance to testify and to examine Porter at trial. A second question, assuming that copying might be proved, was whether the compositions were so similar that the issue of improper use ought also to be decided only after trial. Clark and Frank immediately took opposing sides in a heated exchange of memoranda, and after considerable reflection Hand joined Frank in denying summary judgment. ${ }^{123}$ Clark's dissenting opinion revealed hor strongly he felt about the issue. He referred to "the anti-intellectual and book-burning nature of [the] decision" and characterized the "slightest doubt" gloss on Rule 56 as "ad hoc legislation."124 Many years later, he still objected in bitter terms to the majority opinion. ${ }^{125}$

Clark recovered some ground one year later in California Apparel Creators $v$. Wieder of California, Inc. ${ }^{128}$ A group of California clothiers sought to prevent their New York counterparts from using the name "California" to lure away customers. Clark wrote that a trial

118. Memoranda by Judge Swan in Madeirense do Brasil S/A v. Stulman-Emrick Lumber Co., 147 F.2d 399 (2d Cir. 1945) (Dec. $20 \& 29$, 1944).

119. 149 F.2d 130 (2d Cir. 1945).

120. Id. at 135 .

121. Letter from Judge Frank (May 4, 1945).

122. 154 F.2d 464 (2d Cir. 1946).

123. Memorandum of Judge Clark (Jan. 14 \& 15, 1946), Judge Frank (Jan. 11, 15 \& 16, 1946), and Judge Learned Hand (Jan. 18, 1946) in Arnstein v. Porter, 154 F.2d 464 (2d Cir. 1946).

124. 154 F,2d at $478-80$.

125. Clark, "Clarifying" Amendments, supra note 85, at 249.

126. I62 F.2d 893 (2d Cir.), cert. denied, 332 U.S. 816 (1947). 
was unwarranted since the plaintiffs had not offered specific evidence of harm to each individual business. ${ }^{127} \mathrm{He}$ again had Judge Swan on his side, with Judge Learned Hand dissenting. The previous bitterness surfaced only when Clark asked Hand to delete from his dissent a stern condemnation of unduly liberal summary judgment. Hand reluctantly agreed to soften his language. ${ }^{12 s}$

Thereafter, the battle within the Second Circuit subsided. Clark never again had occasion as a sitting judge to disagree with his colleagues over a denial of summary judgment. ${ }^{129}$ He feared, however, that district judges were no longer granting summary judgment as freely as they should. ${ }^{130}$ His proposed amendment in $1955^{131}$ to Rule 56 was meant to reverse this trend.

On one other aspect of summary judgment Clark sought to use his authority as a judge to promote a reform he had failed to achieve as draftsman. The Advisory Committee had decided not to allow plaintiffs to move for summary judgment in advance of pleading by defendants. The resulting text of Rule 56(a) was too unequivocal to give Clark scope for liberal interpretation. At the first opportunity, in United States $v$. Adler's Creamery, Inc., ${ }^{132}$ he wrote a separate opinion that discussed the disadvantages of the restriction and advocated amendment of the Rule. Within a decade, his view was adopted in an amendment to Rule 56(a)..$^{133}$

When the aim of the pretrial proceedings was to expose the facts prior to trial, Clark again sought to complete reforms he had achieved only partially as Reporter to the Advisory Committee. In the drafting process, Clark had fought strenuously against reliance on pleadings and traditional motions for getting at the facts, deeming modern methods to be much more effective. ${ }^{134}$ As a judge, he continued to support the deposition and discovery devices provided in Rules 26$37^{135}$ and to disparage both the bill of particulars and the less onerous

127. Id. at $900-01$.

128. Memorandum in California Apparel Creators v. Wieder of California, Inc., 162 F.2d 893 (2d Cir. 1947) (Aug. 4, 1947).

129. He still criticized them privately in cases on which he did not sit. Letters to Judges Medina and Waterman (Dec. 27, 1955). For one of several cases in which Clark himself opposed summary judgment, see Anderson v. United States, 182 F.2d 296 (lst Cir. 1950).

130. Letter to Judge Frank (Nov. 12, 1948).

131. P. 928 stupra.

132. 107 F.2d 987, $991-92$ (2d Cir. 1939), cert. denied, 311 U.S. 657 (1940).

133. 6 MoORe's Federal Practice $\int 56.01[3-4]$, at $56-15$ to $56-16$ (2d ed. 1975). As amended in 1946, Rule 56(a) allows plaintiffs to move for summary judgment in advance of the defendant's pleading. FED. R. Civ. P. 56(a).

134. See pp. 917-19 supra.

135. See Moseller v. Unitcd States, 158 F.2d 380 (2d Cir. 1946); Engl v. Aetna Life Ins. Co., 139 F.2d 469 (2d Cir. 1943). 
motion for a more definite statement; he even complained that judges were too literal in applying Rule 12(e), which authorized the latter pleas. ${ }^{136} \mathrm{He}$ finally persuaded the Advisory Committee to propose an amendment, adopted in 1946, that abolished the bill of particulars and narrowed the motion for a more definite statement. ${ }^{137}$

In his only case concerning use of pretrial proceedings under Rule 16 to simplify matters in dispute, Clark faced a much more perplexing conflict between his basic values of efficiency and of deciding cases on their merits. In Padovani $v$. Bruchhausen, ${ }^{13: s}$ the district judge had persistently demanded of the plaintiff a written pretrial statement of the legal theories underlying his cancer claim against a cigarette company. When the plaintiff failed to satisfy the judge, the latter issued a pretrial order effectively barring the plaintiff from trying his claim. ${ }^{139}$ This ruling troubled Clark. He was devoted to Rule 16, and to trial court discretion generally, as aids to judicial efficiency. $\mathrm{He}$ also admired the trial judge and his efforts to clear up docket congestion. ${ }^{1+0}$ Yet for years Clark had strongly opposed the use of pretrial proceedings either to refine pleadings or to suppress litigation on the merits. ${ }^{41}$ Moreover, he felt that the local district courts were seeking to dispose of onerous claims by reversion to special pleading. (He had repulsed one threat in Nagler, ${ }^{142}$ and had attempted to counter another by opposing the new pretrial rules in the Southern District of New York.) ${ }^{\mathbf{1 4 3}} \mathrm{He}$ sought to resolve his dilemma in Padovani by the extraordinary expedient of calling the district judge to urge withdratwal of the order. ${ }^{144}$ When this device failed, Clark wrote a

136. See Nagler v. Admiral Corp., 248 F.2d 319, 323, 326 (2d Cir. 1957); FrC v. Biddle Purchasing Co., 117 F.2d 29, 30 (2d Cir. 1941) (Clark, J., concurring); Clark, The Bar and the Recent Reform of Federal Procelure, 25 A.B.A.J. 22, 23-24 (1939). The original Rule 12(c) dicl not contain the present language, added in 1946, stating that a motion for a more definite statement is proper only" "if a pleading to which a responsive pleading is permitted is so rague or ambiguous that a party cannot reasonably be required to frame a responsive pleading." Fro. R. Civ. P. 19(c) (1946). See 2A Moore's Feder QL Pricrice if $12.17[1]$, at 2359-62, if 12.18[1], at 2387 (2d cd. 1975). The original rule atsthorized the trial judge to grant this motion in a much wider range of circumstances. Id. I 12.17[1], at 2360-61. Clark feared that judges were insisting on excessixc details in the pleading. He preferred that details be disclosed in discorery and depositions. Sec Nagler v. Admiral Corp., 248 F.2d 319, 326 (2d Cir. 1957).

137. Clark, Experience Lnder the Amendments. supra note 100, at 500-01; 21 Moort: Federal Pr.1citice T 12.17[1], at 2359, f 12.18[1], at 2387 (2d ed. 1975). See note 136 supra. 138. 293 F.2d 546 (2d Cir. 1961).

139. Id. at 547 .

140. Memoranda in Padorani v. Bruchhausen, 293 F.2d 546 (2d Cir. 1961) (June 27 \& July 5, 1961).

141. Clark, Objectives of Pre-Trial Procedure, 17 Oно ST. L.J. 169, 167-68 (1956);

Clark, Pre-Trial Orders and Pre-Trial as a Part of Trial, 23 F.R.D. 506, 510 (1958).

142. Pp. 924-25 supra.

143. Clark, To an Understanding Use of Pre-Trial, 29 F.R.D. 454 (1961).

144. Memorandum in Padovani v. Bruchhausen, $293 \mathrm{~F} .2 \mathrm{~d} 546$ (2d Cir. 196I) (July $5,1961)$. 
long opinion that invalidated the order but softened the blow with assurances of support for judicial efficiency. ${ }^{14 J}$

\section{Joinder and Parties}

To a lesser degree, Judge Clark's record on joinder and party issues corresponded with views he had developed as a scholar and rulemaker. Thus, he repeatedly read the Rules to permit wide joinder of causes or parties. ${ }^{1+6}$ This tendency was particularly apparent in cases involving restrictions on the jurisdiction of federal courts which might inhibit joinder. The problem arose when one claim was within a district court's jurisdiction and another, viewed separately, was not. Clark almost invariably held that the second claim could be brought in the district court if it were joined to the first claim.

One line of cases involved the special instance of a tort claim under state law joined to a federal patent, copyright, or trademark claim. In his first case of this type, Lewis $v$. Vendome Bags, Inc., ${ }^{147}$ Clark stated in dissent that for him the only consideration was procedural economy; so long as the two claims had a substantial factual overlap, jurisdiction over both was warranted. ${ }^{14 \mathrm{~s}} \mathrm{He}$ never wavered from this view, but in numerous subsequent cases he was unable to persuade his colleagues. ${ }^{140}$ Therefore, shortly after World War II, he joined Professor Moore in promoting a statute, now 28 U.S.C. $\$ 1338(\mathrm{~b})$, that gave the federal courts jurisdiction over a claim of unfair competition joined to a "related" claim under the copyright, patent, or trademark laws. Fearing that he might not be assigned the first cases under the new law, Clark distributed a long memorandum to his colleagues explaining the statute and imploring them to construe it generously. ${ }^{150}$ At first he found himself again in dissent in Kleinman v. Betty Dain Creations, Inc. ${ }^{151}$ But Clark's position triumphed in 1952, as the panel

145. 293 F.2d at 547-51. For another case involving pretrial procedures that presented Clark with a similar conflict of values, sce Gill v. Stolow, 240 F.2d 669 (2d Cir. 1957). 146. Cases on joinder not discussed in this section include Nagler v. Admiral Corp., 248 F.2d 319, 327-28 (2d Cir. 1957) (allegation of conscious parallelism among 26 corporatc defendants justifies permissive joinder, without regard to legal theories pleaded); MooreMcCormack Lines, Inc. v. McMlahon, 235 F.2d 142, 144 (2d Cir. 1956) (person suing as federal statutory representative of scaman's dependents subject to counterclaim as general representative of seaman's estate).

147. 108 F.2d 16 (2d Cir. 1939), cert. denied, 309 U.S. 660 (1940).

148. Id. at 18-21.

149. E.g., Zalkind v. Scheinman, 139 F.2d 895 (2d Cir. 1943), cert. denied, 322 U.S. 738 (1944) (Clark, J., dissenting); Musher Foundation, Inc. v. Alba Trading Co., $127 \mathrm{~F} .2 \mathrm{~d}$ 9, 11 (2d Cir.) (Clark, J., dissenting), cert. denied, 317 U.S. 641 (1942); Treasure Imports, Inc. v. Henry Amdur \& Sons, 127 F.2d 3 (2d Cir. 1942) (Clark, J., dissenting).

150. Memorandum to Second Circuit judges (Jan. 23, 1951).

151. 189 F.2d 546 (2d Cir. 1951). 
in Telechron, Inc. v. Parissi ${ }^{152}$ read the statute to authorize broad joinder.

Another line of cases involved aspects of ancillary jurisdiction, including diversity of citizenship and venue requirements. Clark's first opinion on the subject, Lesnik v. Public Industrials Corp., ${ }^{153}$ held merely that a counterclaim clearly compulsory under Rule 13(a) did not require its own basis for venue. Clark supplemented this, however, with a full discussion of the policy and precedents supporting broad joinder. ${ }^{154}$ Moreover, he sought to extend the holding to subject matter jurisdiction as well as venue and to counterclaims only arguably compulsory. Judge Learned Hand prevented him from articulating these views, ${ }^{155}$ but he did manage to insert a good deal of suggestive language. ${ }^{156}$

Ten years later, with a more friendly panel of fellow Connecticut judges, Clark was able to extend the ruling openly. In United Artists Corp. v. Masterpiece Productions, Inc., ${ }^{157}$ he declared that compulsory counterclaims did not need their own basis of subject matter jurisdiction. He construed the last phrase in Rule 13(a), barring counterclaims against "third parties of whom the court cannot acquire jurisdiction," as referring only to personal jurisdiction. ${ }^{158} \mathrm{He}$ also defined compulsory counterclaims exceedingly broadly: Rule 13(a)'s requirement of a single "transaction or occurrence" was satisfied if the facts of the two claims were related "logically." 159 Thus, in United Artists it was sufficient for ancillary jurisdiction that the counterclaim adduced, as one piece of evidence of a plan to violate the defendant's rights, the filing of the original claim by the plaintiff in collaboration with the third-party defendants. ${ }^{160}$

Under the circumstances, one might have supposed that Friend $v$. Middle Atlantic Transp. Co. ${ }^{161}$ was particularly painful for Clark. He held that Rule 14 exceeded statutory limits by authorizing ancillary jurisdiction over a third-party defendant impleaded solely on account of liability to the original plaintiff. In his opinion Clark repeatedly expressed reluctance to limit impleader. He wrote as if com-

152. 197 F.2d 757, 759.61 (2d Cir. 1952), cert. denied, 348 U.S. 860 (1954).

153. 144 F.2d 968, $973-75$ (2d Cir. 1944).

154. Id. at 973-77.

155. Memoranda in Lesnik v. Public Indus. Corp., 144 F.2d 968 (2d Cir. 1914) (Aug. 8 \& 18, 1944).

156. 144 F.2d at 975-i 7 .

157. 221 F.2d 213, 216 (2d Cir. 1955).

158. Id. at 216-17.

159. Id. at 217 .

160. Id. at 214,217 .

161. 153 F.2d 778 (2d Cir.), cert. denied, 328 U.S. 865 (1946). 
pelled by scholarly opinion and kept his holding narrow, excluding related cases in which the third-party defendant might be liable for contribution. ${ }^{102}$ In a private letter, he suggested that he had been talked into this position by his academic colleague, Professor Moore, to whom he had turned for advice. ${ }^{103}$ Yet Clark probably approved of the holding. While the Rules were being drafted, he had objected to the impleader of third-party defendants liable only to the original plaintiff, ${ }^{104}$ and a decade later he joined the Advisory Committee in urging that this form of joinder be abolished, a proposal pending at the time Friend was decided. ${ }^{105} \mathrm{~A}$ memorandum to the other judges on the panel reveals that Clark's reluctance to limit Rule 14 was mainly due to his desire not to let down fellow reformers who favored expansive impleader. ${ }^{166}$

Clark was not satisfied simply to allow joinder desired by the parties. His desire to compel them, in certain situations, to combine their claims is illustrated by his unfolding views concerning res judicata in class suits. Since he expressed few ideas on this subject before coming to the bench, he was more likely to change his mind here than in other contexts. During his first decade as a judge, he took a conventional approach; in terms now obsolete, he asserted that "true" and "hybrid" class suits would support ancillary jurisdiction and bind the entire class, while "spurious" class suits would do neither. ${ }^{107}$ As scholarly thought gradually shifted in favor of giving greater effect to spurious class suits, however, so did Clark's. In the early 1950's he began exploring the possibility of imposing res judicata

162. Id. at 780. In support of his criticism of Rule 14, Clark cited Professor Moore and the Advisory Committee's proposal for an amendment of the Rule. Id.

163. Letter to Armistead Dobic (Mar. 8, 1946).

164. P. 919 supra.

165. Clark, The Amended Federal Rules, 15 BrookLyN L. Rev. 1, 2 (1948); Clark, Experience Under the Amendments, supra note 100, at 499.

166. Memorandum in Friend v. Middle Atl. Trans. Co., 153 F.2d 778 (2d Cir. 1946) (Feb. 15, 1946).

167. California Apparel Creators v. Wieder of California, Inc., 162 F.2d 893, 895 (2d Cir.), cert. denied, 332 U.S. 816 (1947); Central Mexico Light \& Power Co. v. Munch, 116 F.2d 85, 88 (2d Cir. 1940).

Prior to its amendment in 1966, Rule 23 provided for three types of class actions. A "true" class action involved an action to support a right that was joint, common, or secondary in the sense that the owner of the primary right declined to enforce it, thereby entitling members of the class to do so. The class action was "hybrid" when the right to be enforced was "several" but the object of the action was the settlement of claims affecting property involved in the action. "Spurious" class suits involved actions that contained common questions of law or fact and asked for common relief, although they involved "several" rights. 3B Moore's Federal Practice If 23.01[1]-[13] (2d ed. 1975). The 1966 amendments to Rule 23 abolished these categories of class actions based on jural rights and substituted more practical criteria for permitting class actions. $I d$. 
on all members of the spurious class, assuming that notice and representation were adequate. ${ }^{108} \mathrm{He}$ also supported an amendment to the Rules that provided for proper notice and representation in class suits as a means of facilitating binding judgments. ${ }^{169}$

Clark never actually held a judgment in a spurious class suit to be res judicata. Instead he expanded use of the "true" and "hybrid" categories, to which res judicata clearly applied. Stella $v$. Kaiser, ${ }^{170}$ a typical case, presented the question of whether a judicially-approved compromise in a stockholders' derivative suit was binding against the plaintiffs in a second suit against a director who had been dropped as defendant in the prior suit. Clark's initial negative reaction was perhaps motivated by his hostility to manipulative corporate directors. ${ }^{171}$ As he prepared a draft opinion, however, he recalled Rule 23(a), which suggested to him that the original stockholders' derivative suit had been both a plaintiffs' and a defendants' "true" class action. ${ }^{172}$ Clark found that this was the most satisfactory ground for deciding the case, although none of the parties hạd characterized the suit as a class action of any kind. ${ }^{173}$ Judges Learned Hand and Frank concurred on a much more conventional ground.

On party questions other than joinder, Clark's judicial work again reflected his longstanding views. He preferred a simple test of who might sue, as illustrated by his reaction to a case on which he did not sit, Edward B. Marks Music Corp. v. Jerry Vogel Music Co. ${ }^{174}$ There, Judge Learned Hand, having acknowledged the rule that the legal owner of a copyright had the right to sue, assumed for convenience in argument that under Rule 17 (a) the "real party in interest" might instead be the beneficiary of the copyright. ${ }^{175}$ Clark immediately wrote Hand, protesting angrily that this assumption was contrary to the Advisory Committee's understanding that the real party in interest was simply the person with the right to sue under substantive law. ${ }^{176}$ When Hand replied that he had not held to the con-

16S. See Gart v. Colc, 263 F.2d 244 (2d Cir.), corl. denicd, 359 U.S. 978 (1959); Stella v. Kaiser, 218 F.2d 64 (2d Cir. 1954); Dickinson v. Burnham, 197 F.2d 973 (2d Cir.), cert. denied, 344 U.S. 875 (1952).

169. 1955 REPORT, supra note 62 , at $26-28$.

170. 218 F.2d 64 (2d Cir. 1954).

171. See letter to Paul Crouch (Feb. 28, 1944).

172. Memoranda in Stella v. Kaiser, 218 F.2d 64 (2d Cir. 1954) (Oct. 15 \& 27, 1954). Original Rule $23(a)(1)$ provided for "true" class actions. See note 167 supra.

173. 218 F.2d at 67.

174. 140 F.2d 268 (2d Cir. 1944). Other examples are Blau v. Lamb, 314 F.2d 618 (2d Cir.), cert. denied, 375 U.S. 813 (1963); Rosenblum v. Dingfelder, 111 F.2d 406 (2d Cir. 1940).

175. 140 F.2d at 269.

176. Letter to Judge Learned Hand (Jan. 29, 1944). 
trary, Clark insisted that he had done grave harm by raising the question and intimating the rrong answer. ${ }^{177}$

In cases involving the substitution of parties, Clark also espoused his liberal approach.17s $\mathrm{He}$ was not obstinate on this subject, however, and could defer when he felt that the law was clearly against him. Vibra Brush Corp. v. Schaffer ${ }^{179}$ involved the issue of whether, under the Second Circuit's Rule 9 (which resembled Federal Rule 25(d)), the period for substituting government officials as defendants began when the permanent successor took office or from the earlier date when a temporary stand-in was installed. Clark believed that when the actual defendant was the Government itself, substitution should not be required until the permanent successor took office. Indeed, he had persuaded the Advisory Committee to propose an amendment to Rule 25(d) whereby no substitution whatever was necessary in such cases, ${ }^{150}$ and he regarded this as the most crucial of the proposals not adopted by the Supreme Court in 1955.181 While Vibra Brush was pending, however, the Supreme Court rendered a pair of per curiam decisions, applying its own substitution rule (also modeled after Rule 25(d)) and starting the time period at the appointment of temporary successors. ${ }^{182}$ Clark's first instinct was to disregard these rulings, in part on the ground that the Second Circuit's Rule could be interpreted independently. Upon further consideration he became persuaded that the Rules should be construed uniformly and reluctantly concluded that the appeals had to be dismissed.183 However, he assigned the opinion to himself and rebuked the Supreme Court, not only for its decisions but for having failed to amend Rule 25(d). ${ }^{194}$ Ultimately Clark prevailed, as the amendment was enacted in 1961. ${ }^{185}$

177. Letter from Judge Learned Hand (Jan. 31, 1944); letter to Judge Learned Hand (Feb. 2, 1944).

178. E.g., Hirsch v. Bruchhausen, 284 F.2d 783 (2d Cir. 1960); Hackner v. Guaranty Trust Co., 117 F.2d 95 (2d Cir.), cert. denied, 313 U.S. 559 (1941).

179. 256 F.2d 681 (2d Cir. 1958).

180. 1955 RePORT, supra note 62 , at 28-33.

181. See letter to Edmund Morgan (Apr. 6, 1953).

182. Klaw v. Schaffer, 357 U.S. 346 (1958); Glanzman v. Schaffer, 357 U.S. 347 (1958).

183. Memoranda in Vibra Brush Corp. v. Schaffer, 256 F.2d 681 (2d Cir. 1958) (June 26, July $7 \& 23,1958$ ).

184. 256 F.2d at $683-84$.

185. 3B Moore's Federal Practice $\int 25.01[1]$, at 25-21 to 25-22 (2d ed. 1975).

Clark also expressed his views on various trial and appeliate procedures. On the admission of pretrial depositions at trial (Rule 32(a)), see Klepal v. Pennsylvania R.R., 229 F.2d 610 (2d Cir. 1956); Arnstein v. Porter, 154 F.2d 464, 475 (2d Cir. 1946) (Clark, J., dissenting). On special verdicts and interrogatories (Rule 49), see Morris v. Pennsylvania R.R., 187 F.2d 837 (2d Cir. 1951). On revicw of district court findings (Rule 52(a)), see Heim v. Universal Pictures Co., 154 F.2d 480, 488 (2d Cir. 1946) (Clark, J., concurring); Clark, "Clarifying" Amendments, supra note 85, at 247. On the use of masters 


\section{E. Rule 54(b)}

The manner in which Clark handled piecemeal appeals under Rule $54(b)$ is the most illuminating aspect of this study. ${ }^{186}$ The problem arose when a district judge disposed of one of several claims or a claim by or against one of several parties but retained the rest of the action for further proceedings. The question was whether the loser could appeal immediately or only after disposition of the entire suit. On this issue, unlike most arising under the Rules, Clark came to the bench without well-developed viervs. The issue came up repeatedly and caused much controversy. The rule was substantially changed by amendment after a decade, creating new interpretative difficulties. As a result, Clark spent more time and energy developing his position and underwent a more complex intellectual development than on any other procedural problem with which he dealt as a judge. It was also one of the issues about which he came to feel most strongly.

As originally adopted, Rule 54(b) provided: "When more than one claim for relief is presented in an action, the court at any stage, upon a determination of the issues material to a particular claim and all counterclaims arising out of the transaction or occurrence which is the subject matter of the claim, may enter a judgment disposing of such claim." 187 According to Rule 54(a), this judgment was subject to immediate appeal. Thus, whether a piecemeal appeal was permitted under the Rules depended on the definitions of "claim" and "transaction or occurrence."

Collins v. Metro-Goldwyn Pictures Corp., ${ }^{\text {sss }}$ Clark's first Rule 54(b) case, showed his lack of well-developed views on the problem. The trial court had dismissed a copyright action ${ }^{189}$ involving the contents

(Rule 53(b)), see De La Rama S.S. Co. v. United States, 206 I.2d 65I, 650 (2d Cix. 1953) (Clark, J., dissenting); NLRB v. Giannasca, 119 F.2d 756, 758 (2d Cir. 1941) (Clark, J., concurring); Clark, Difficulties Encountered in a System of Maslers, 23 F.R.D. 569 (1958). On the time for appeal (Rule 58), see Matteson v. United States, 240 F.2d 517 (2d Cir. 1956); F. \& M. Schaefer Brewing Co. v. United States, 236 F.2d 889 (2d Cir. 1956), rev'd, 356 U.S. 227 (1958); United States v. Wissahickon Tool Works, 200 F.2d 936 (2d Cir. 1952). On district court revision of judgments affirmed by an appellate court (Rule 60), see S. C. Johnson \& Son v. Johnson, 175 F.2d 176, 180 (2d Cir.) (Clark, J., dissenting), cert. denied, 338 U.S. 860 (1949); Perlman v. 322 West $72 \mathrm{~d}$ St. Co., 127 F.2d 716 (2d Cir. 1942); Clark, "Clarifying" Amendments, supra note 85, at 250. On the trial of condemnation cases (Rule 71A), sce United States v. Bobinski, 244 F.2d 299 (2d Cir. 1957); United States v. 44 Acres of Land, 234 F.2d 410, 416 (2d Cir.) (Clark, J., concurring), cert. denied, 352 U.S. 916 (1956); Clark, The Proposed Condemnation Rule, 10 Oнг ST. L.J. 1 (1949).

186. Compare M. ScHick, supra note 2 , at $229-40$, which contains less doctrinal analysis but describes additional cases and goes into greater detail on the controversy between Clark and Frank.

187. FED. R. Civ. P. 54(b) (1938).

188. 106 F.2d 83 (2d Cir. 1939).

189. I use the term "action" instead of "claim" in order to avoid confusion with the wording of Rule 54(b). 
of a book while an unfair competition action involving the title was still pending: ${ }^{100}$ Clark never reached a firm conclusion on whether the ruling was appealable. Indeed, his approach appeared to shift halfway through deliberations on the case. Clark's first instinct, in accord with his underlying procedural values, was to ask whether convenience and economy would be served by allowing an immediate appeal. He was also inclined, as usual, to defer to the trial judge's view on this issue. ${ }^{191}$ These considerations pointed toward permitting the appeal, the position he ultimately took in the case. But at the urging of Professor Moore, whom he had consulted on the case, Clark's attention shifted to matters of doctrinal logic. He became concerned that if the word "claim" in Rule 54(b) were construed narrowly, the same would have to be done on other issues, such as joinder, where he definitely favored a broad definition. ${ }^{192}$ Rather than opposing review, however, Clark wrote a concurring opinion asserting that the same words might be interpreted differently in different contexts, depending on their functions. ${ }^{193}$

In his next major case on the issue, Sidis v. F-R Pub. Corp., ${ }^{194}$ Clark resolved his dilemma in the opposite way. He acknowledged that if procedural convenience were the governing consideration, he would have voted to allow the appeal.195 But now he emphasized doctrinal consistency, suggesting in a separate statement that the same words in different Rules could not be given a different interpretation. An appropriately broad interpretation of the word "claim" meant that the appeal should never have been heard. ${ }^{196}$

This trend in Clark's development was strongly confirmed by Musher Foundation, Inc. v. Alba Trading Co., ${ }^{197}$ in which the district judge had dismissed an unfair competition action under state law for lack of jurisdiction while a federal patent action was still pending. The case presented itself to Clark primarily as a problem of pendent jurisdiction, and since the concepts underlying that issue were similar to those in Rule 54(b), the case underlined for Clark the desirability of a doctrinally consistent approach. He was firmly committed to reading the concepts broadly for pendent jurisdiction pur-

190. 106 F.2d at 84 .

191. Memorandum in Collins v. Metro-Goldwyn Pictures Corp., 106 F.2d 83 (2d Cir. 1939) (May 24, 1939).

192. Memorandum in Collins v. Metro-Goldwyn Pictures Corp., 106 F.2d 83 (2d Cir. 1939) (July 28, 1939).

193. 106 F.2d at 86-87.

194. 113 F.2d 806 (2d Cir.), cert. denied, 311 U.S. 711 (1940).

195. 113 F.2d at 811 .

196. Id.

197. 127 F.2d 9 (2d Cir.), cert. denied, 317 U.S. 641 (1942). 
poses, asking merely whether there was a substantial factual overlap between the actions. Applied to piecemeal appeals, this interpretation would oblige him to deny review in the great majority of cases. Thus, Clark not only dissented from the majority opinion sustaining the appeal but announced that he had voted wrongly in Collins. ${ }^{10 \mathrm{~s}}$

By 1943 , in Audi Vision, Inc. v. RCA $M$ Ifg. Co., ${ }^{100}$ Clark had brought together his opposition to piecemeal appeals and his underlying procedural values. Perhaps his work with Professor Moore on an amendment to Rule 54(b) focused his attention on the merits of the problem and not just on doctrinal logic. ${ }^{200} \mathrm{He}$ may also have been influenced by the fact that his adversary, Judge Frank, was drafting a new statute on interlocutory appeals, which took an approach that differed from his own and Moore's. Whatever the explanation, although Audi Vision was a simple case of nonappealability, Clark wrote an extensive opinion on the entire topic of piecemeal appeals. He acknowledged, as he had previously, that "undoubtedly there will be times when in the actual posture of a case a short-cut ruling may be helpful." But he was now satisfied that "in the long run fragmentary disposal of what is essentially one matter is unfortunate... for the waste of time and expense caused the parties and the courts." Moreover, he asserted, "there is an unfortunate tendency under such a system to stress decisions on pure points of procedure . . . with the unfortunate consequence of shifting emphasis from merits to form." 201

In subsequent cases Clark gradually put aside his concern for economy and increasingly opposed premature appeals because they promoted excessive emphasis on procedural issues. ${ }^{202}$ In this way, he came to see his whole program of procedural reform as dependent upon the restriction of piecemeal review. He again was opposed by Judge Frank, who favored wider interlocutory appeal. These circumstances led to another bitter clash within the Second Circuit.

In Zarati S.S. Co. v. Park Bridge Corp., ${ }^{203}$ Clark applied his views to a case of multiple parties. The action against the charterer of a ship was still pending, while those against the charterer's sales agent and his financer had been dismissed. The majority allowed the appeal on the ground that the defendants did not have "joint" inter-

198. Id. at 11-13.

199. 136 F.2d 621 (2d Cir. 1943).

200. See pp. $941-42$ infra.

201. $136 \mathrm{~F} .2 \mathrm{~d}$ at 625 .

202. Libbey-Owens-Ford Glass Co. v. Sylvania Indus. Corp., 154 F.2d 814 (2d Cir.). cert. denied, 328 U.S. 859 (1946); Zalkind v. Scheinman, 139 F.2d 895, 905 (2d Cir: 1913) (Clark, J, dissenting), cert. denied, 322 U.S. 738 (1941).

203. 154 F.2d 377 (2d Cir. 1946). 
ests, ${ }^{204}$ but Clark contended in dissent that so long as the actions turned substantially on common questions of fact they could not be appealed separately. ${ }^{2 n-5}$ This was the same test he had previously adopted for cases involving single parties.

In only one case under the original Rule 54(b), aside from Collins, did Clark favor piecemeal appeal, and there his usual opposition was greatly outweighed by another cherished procedural value. In California Apparel Creators 0 . IVieder of California, Inc., ${ }^{206}$ a California trade association and 75 of its members brought an unfair competition suit against three New York corporations. Clark held that each plaintiff's cause of action against each defendant was appealable separately. ${ }^{207}$ This holding could not be reconciled with his prior decisions, for the rest of his opinion concerned questions common to all the parties. Clark's behavior may be explained by the fact that he wished to portray the suit as a conglomeration of individual claims in order to regain ground in his summary judgment campaign, following his defeat in Amstein v. Porter: ${ }^{20 s}$ Moreover, an amendment to Rule 54(b) was about to go into effect, and therefore the decision had almost no precedential significance.

Clark had been working with Professor Moore on this amendment to Rule $54(\mathrm{~b})$ for some time. His original intention was to codify his own views, ${ }^{209}$ but later he became reconciled to a compromise amendment, which went into effect in 1948 and provided:

When more than one claim for relief is presented in an action, whether as a claim, counterclaim, cross-claim, or third-party claim, the court may direct the entry of a final judgment upon one or more but less than all of the claims only upon an express determination that there is no just reason for delay and upon an express direction for the entry of judgment. In the absence of such determination and direction, any order or other form of decision, however designated, which adjudicates less than all the claims shall not terminate the action as to any of the claims . . . . ${ }^{210}$

204. Id. at 379 . Original Rule $54(\mathrm{~b})$ did not refer specifically to multiple parties. P. 938 supra. The Rule allowed appeal of an action by or against one of several parties only when it constituted a "claim" separate from the rest of the case. This condition was absent, according to the prevailing view, whenever the multiple parties had "joint interests," a test abounding in fine distinctions. 6 Moore's Federal Practice If 54.23[4], at 257.60 (2d ed. 1975). A 1961 amendment made Rule 54(b) applicable to multiple partics. Id. \54.29[3], at 426-27.

205. I54 F.2d at 381-82.

206. 162 F.2d 893 (2d Cir.) cert. denied, 332 U.S. 816 (1947).

207. Id. at 902.

208. 154 F.2d 461 (2d Cir. 1946). See pp. 930-31 supra.

209. See 6 Moore's Federat. Practice if 54.26, at 301-03 (2d ed. 1975) (discussing the amendment that would have codified Clark's views).

210. FED. R. CIv. P. 54(b) (1948). 
The latter decision thus was not immediately appealable.

The Advisory Committee Note suggests that the amendment served three purposes. First, it strengthened the policy against premature review by placing the burden of establishing no just reason for delay on the losing parties. ${ }^{211}$ Unless the district judge faced the issue and made a formal determination of finality, immediate review would not be permissible. Second, the amendment provided a safety valve for unusual cases in which the district judge thought immediate appeal to be especially appropriate. ${ }^{212}$ Clark later asserted that this aspect of the new Rule was purely a concession to his adversaries, particularly Judge Frank. ${ }^{213}$ But it is possible that Clark also sympathized with the safety valve notion since it corresponded to his initial reaction to the piecemeal appeals question in Collins. ${ }^{214}$ Third, the amendment reduced the burden of procedural litigation for everyone involved in the case. If the district judge did not make a determination of finality, that was the end of the matter. Even if the judge did so, in most cases that would also settle the issue, for the scope of allowable appeals was at least as broad under the amended rule as under Frank's construction of original Rule 54(b). ${ }^{215}$

In fact, it was many years before the amendment settled the issue of piecemeal appeals. The main point of controversy which developed was whether even more orders were now potentially appealable than under Judge Frank's view of the old Rule. In doctrinal terms, the controversy turned on whether "claim" should be construed more narrowly than by the previous jointness test used under the original Rule.216 As a practical matter, this would determine whether dismissal of one of several parties was always separately appealable. If so, the new Rule would be usable as a safety valve in the most pressing situation of all, complete dismissal of a defendant. This approach would also simplify disposition of procedural issues by providing an easy solution in multiple party cases. On the other hand, a narrow interpretation of the word "claim" would further weaken the policy against piecemeal review and would be difficult to justify under the language of the amendment, for no one had suggested that "claim" was to be interpreted in a new way. Some even questioned the validity

211. United States Supreme Court, Advisory Committre on Rules for Civil Procedure, Report of Proposed Amendmests to Rules of Givil Procedure for the DisTRICT Courts of THE UNITEd Statrs 70- 72 (1946) [hereinafter cited as 1946 Rerort].

212. Id.

213. Memorandum in Pabellon v. Grace Linc, $191 \mathrm{~F} .2 \mathrm{~d} 169$ (2d Cir. 195l) (July $20,1951)$.

214. See pp. 938-39 supra.

215. 1946 Reporr, supra note 211, at 70-72.

216. See note 204 supra. 
of the Rule under this interpretation, claiming that it would enlarge the jurisdiction of the courts of appeals contrary to the spirit of Rule 82..217

Clark's first discussion of amended Rule $54(\mathrm{~b})$ as a judge was surprisingly ambiguous on this issue. In a dissenting opinion in Lo Bue v. United States, ${ }^{218}$ he issued a dictum supporting the validity of the new Rule. His assertion that its only purpose had been to create a presumption against finality absent express action by the district court suggested that the bounds of appealability had not been enlarged.919 Yet the example he gave of a situation testing these bounds, a grant of permission to amplify a complaint, was so extreme as to intimate that they had been expanded. ${ }^{220}$

Within the next two years, Clark resolved the issue in favor of a wide scope of appealability under the new Rule. Presumably he thought that reducing the burden of litigation on this procedural subject was of prime importance. ${ }^{221}$ For both personal and policy reasons he probably also wished to undercut Judge Frank's proposal for a legislative expansion of interlocutory appeals. ${ }^{222}$ At the same time, the requirement of a formal determination of finality by the district judge hopefully would ensure against excessive piecemeal appeals. ${ }^{223}$ To be sure, Clark's view dictated a narrow reading of "claim," whereas in other settings he preferred a broad construction. Apparently he had reverted to his contention in Collins that the same word might be interpreted differently in different contexts, depending on its function. ${ }^{224}$

Meanwhile Judge Frank had written an opinion in Republic of China v. American Express Co., ${ }^{225}$ stating in dictum that the amendment had not enlarged appealability. Clark expressed displeasure that this had been done in a case in which he was not a member of the panel, and he resolved to record his views at the next opportunity. ${ }^{226}$ The first case to present such an opportunity, Pabellon $v$. Grace Line, Inc. ${ }^{227}$ involved the dismissal of third and fourth-party indemnity actions against the suppliers and makers of defective goods while the

217. Rule 82 provides that the Federal Rules "shall not be construed to extend or limit the jurisdiction of the United States district courts . . . ."

218. 178 F.2d 528 (2d Cir. 1949).

219. Id. at 531 n.I.

220. Id.

221. Sce p. 942 supra.

222. See memoranda in Pabellon v. Grace Line, Inc., 191 F.2d 169 (2d Cir. 195l)

(June 14 \& 26, 1951); M. ScHick, supra note 2, at 229-40.

223. See p. 942 supra.

224. See pp. 938-39 supra.

225. 190 F.2d 334 (2d Cir. 195I).

226. Letter to Judge Frank (June 14, 1951).

227. 191 F.2d 169 (2d Cir.), cert. denied, 342 U.S. 893 (1951). 
original tort action brought by the person injured by the goods was still pending. Clark conceded in his opinion for the court that the orders were appealable under the old Rule, and Judge Frank agreed;:2:s indeed, none of the parties had questioned this. In a memorandum to the other members of the panel, Clark acknowledged that the district judge had misused his power to make the orders final, presumably because the requirement in the new Rule that there be "no just reason for delay" had not been met..29 But he also asserted that the time was right to clarify misconceptions about amended Rule 54(b). ${ }^{230}$ Accordingly, he stated in his opinion, on the authority of Professor Moore, that "it is within the district judge's power to make certain orders final that would not have been final under the original rule." 231 On this point, Frank disagreed vigorously. 232

As in the case of summary judgment, ${ }^{233}$ Clark was promptly rebuffed by a panel on which he did not sit. In Flegenheimer v. General Mills, Inc., ${ }^{234}$ decided eight days after Pabellon, the senior members of the court, Judges Learned Hand, Augustus Hand, and Swan, declined to be bound by Pabellon because the views expressed were clearly unnecessary to the decision. They read amended Rule 54(b) as not expanding appealability, suggesting that if it had done so it would be invalid. ${ }^{235}$ This narrow reading of the amended Rule strengthened the argument that a new statute on interlocutory appeals was still necessary, and one month later Frank submitted to the Judicial Conference of the United States a revised legislative proposal. His action was particularly galling to Clark because Frank cited Professor Moore, Clark's former ally, as a proponent of the legislation..$^{236}$

Now that his mind was made up, Clark fought back, as in Arnstein v. Porter, ${ }^{237}$ with fierce determination. In Lopinsky v. Hertz DriveUr-Self Systems, Inc. ${ }^{238}$ which arose out of an automobile accident, the action against the car rental company was dismissed while those against the company's customer and its local agence were still pending.

228. Id. at 173; id. at 176 (Frank, J., concurring).

229. See Luckenbach S.S. Co. v. H. Muehlstein \& Co., 280 F.2d 775, 777-79 (2d Cir. 1960).

230. Memoranda in Pabellon v. Grace Line, Inc., 191 F.2d 169 (2d Cir. 1951) (June $14 \& 26,1951)$.

231. 191 F.2d at 173 .

232. Id. at 176 (Frank, J., concurring).

233. See p. 930 supra, discussing Dochler Metal Furniture Co. v. United States, 149

F.2d 130 (2d Cir. 1945).

234. 191 F.2d 237, 241 (2d Cir. 1951).

235. Id.

236. Letter to Edmund Morgan (Apr, 6, 1953).

237. 154 F.2d 464 (2d Cir. 1946). See p. 930 supra.

238. 194 F.2d 422 (2d Cir. 1951). 
It is unclear whether, as Clark claimed, the dismissal would have been appealable under the old Rule. In any event, Judges Augustus Hand and Swan affirmed in a per curiam opinion that did not even mention the Rule 54(b) problem. Clark's long concurring opinion, by contrast, covered the whole subject and featured the strained argument that if a liberal interpretation of the new Rule 54(b) were invalid, so were a score or more of other Federal Rules relating to appellate practices. ${ }^{239} \mathrm{He}$ also criticized the panel in Flegenheimer for its "flat repudiation" of "the confines of precedent," for having given him "no notice of the impending doom" of Pabellon, and for "describing opprobriously" his "hard work as only 'dictum." "'40 Clark admitted several years later that his language may have been offensive, but he still thought it entirely justified.211

After this outburst, Clark let the issue pass by in silence in Colonial Airlines, Inc. $v$. Janas, ${ }^{2+2}$ though he indicated in his memorandum to the other members of the panel that the case might be used to overturn Flegenheimer. ${ }^{243}$ But he encouraged liberal interpretations of Rule 54(b) in other courts, sending a copy of his opinion in Lopinsky to the Third Circuit while it was considering the issue en banc. ${ }^{244}$ He persuaded the Advisory Committee to propose a further amendment to Rule 54(b) that would overturn Flegenheimer by expressly permitting appeal in all multiple-party cases. ${ }^{245}$ And he fought Judge Frank's legislative proposal within the Judicial Conference.94b

When these efforts were not wholly successful, Clark again sought to establish his viewpoint within the Second Circuit. United Artists Corp. v. Masterpiece Productions, Inc., ${ }^{2+7}$ a very liberal decision on ancillary jurisdiction, also posed the issue of appealability in a fairly extreme way. Actions against three business executives had been dismissed while the action against their company, with which they were accused of conspiring, was still pending. Although the parties had not raised the issue, and no one had mentioned it at the case conference, Clark ventured to suggest in his draft opinion that dismissal of one

239. Id. at 424-30.

240. Id. at 429 \& n.16.

241. Letter to Justice Frankfurter (Sept. 29, 1954).

242. 202 F.2d 914 (2d Cir. 1953).

243. Memorandum in Colonial Airlines, Inc. v. Janas, 202 F.2d 914 (2d Cir. 1953) (Janl. 15, 1953).

244. See letter from Harriet Humphress (Dec. 17, 1951).

245. See 1955 Rerorr, supra note 62, at 54. This amendment was rejected by the Supreme Court in 1955 but was finally adopted in 1961. 6 MOORE's Federal Practice [f 54.01[6-1], at 54, I 54.29[3], at $426-27$ (2d cd. 1975).

246. Letter to the Judicial Conference of the United States (Scpt. 11, 1951).

217. 221 F.2d 213 (2d Cir. 1955). For a cliscussion of this case in the context of ancillany jurisdiction and compulsory coumerclaims, sec p. 934 supra. 
of several parties was always separately appealable. When Judge Hincks showed doubt, ${ }^{248}$ Clark called on other members of the court to help allay Hinck's concern, ${ }^{49}$ and the opinion came down substantially as drafted.250

Clark's final skirmish on this matter occurred a few months later in Rieser $v$. Baltimore \& Ohio Railroad. ${ }^{251}$ The judgment below was appealable under any view of Rule 54(b), as Clark himself acknowledged..52 But the Supreme Court had granted certiorari to resolve the issue of appealability after dismissal of a party, and Clark was determined to influence the Court. ${ }^{253}$ Accordingly, he wrote another exhaustive opinion defending his liberal views on appealability. ${ }^{254}$ To assure that his opinion was seen by the Supreme Court, he had copies sent to lawyers involved in the case..$^{255}$

There was a mixed outcome to the dispute on this issue. The Supreme Court interpreted the existing Rule substantially as Clark advocated. ${ }^{256}$ It temporarily shelved the amendment sought by Clark, but in 1961, two years before his death, it finally adopted the present Rule 54(b), which covers multiple parties. On the other hand, in 1958 Congress enacted a modified version of Judge Frank's proposal, the present $\S 1292(b)$ of the Judicial Code, ${ }^{257}$ allowing certain interlocutory appeals. Clark did his best to narrow the statute by judicial interpretation and criticized what remained of it..5s

Even during the dispute over amended Rule 54(b), Clark had indicated his continuing opposition to piecemeal review outside this Rule. An important source of such review was the collateral order doctrine, whereby procedural "offshoots" of litigation were appealable separately. Clark repeatedly sought to subject the cases to amended Rule 54(b), which ordinarily would have precluded review. ${ }^{259}$ Failing

248. Memorandum in United Artists Corp. v. Mastcrpicce Prods., Inc., 221 F.2d 213 (2d Cir, 1955) (Mar. 14, 1955).

249. Letter to Judge Medina (Mar. 12, 1955).

250. 221 F.2d at $215-16$.

251. 224 F.2d 198 (2d Cir.), cert. denied, 350 U.S. 1006 (1955).

252. Id. at 199-200.

253. Memorandum in Ricser v. Baltimore \& O.R.R., 224 F.2d 198 (2d Cir. 1955) (Apr. $28,1955)$.

254. $224 \mathrm{~F} .2 \mathrm{~d}$ at $200-04$.

255. Letter to Leland Tolman (June 8, 1955).

256. See Sears, Roebuck \& Co. v. Mackey, 351 U.S. 427 (1956).

25\%. 28 U.S.C. $\$ 1292$ (b) (1970).

258. See Gottesman v. General Motors Corp., 268 F.2d 194 (2d Cir. 1959); Brown v. Bullock, 294 F.2d 415, 422 (2d Cir. 196I) (Clark, J., concurring); Matthies v. Seymour Mfg. Co., 271 F.2d 740 (2d Cir.) (Clark, J., dissenting), cert. denied, 361 U.S. 962 (1959).

259. Harmar Drive-In Theater v. Warner Bros. Pictures, 239 F.2d 555, 557 (2d Cir.) (Clark, J., dissenting), cert. denied, 355 U.S. 824 (1956); Republic of Italy v. De .Ingelis, 206 F.2d 121, 126 (2d Cir. 1953) (Clark, J., concurring). 
to convince his court, he sought unsuccessfully to obtain from the Advisory Committee an amendment to the same effect. ${ }^{260}$

Therefore, it is not surprising that when the battle over piecemeal appeals had ended, Clark began to emphasize the limits of Rule 54(b). He may have felt that a safety valve was no longer strategically necessary since Frank was now dead and Congress had enacted the interlocutory appeals statute despite Clark's opposition. Moreover, he may have thought that the issue no longer produced such an excessive amount of litigation that a permissive reading of the Rule was of prime value. In any event, in his final shift of position on Rule 54(b), he reverted to his earlier policy against piecemeal review.

Two 1960 cases illustrate the shift. Luckenbach Steamship Co. v. Muehlstein \& Co., ${ }^{201}$ in which a third-party indemnity action against the supplier of defective equipment was dismissed while the original tort action by the injured person was still pending, resembled $P a$ bellon. ${ }^{202}$ The district judge had not yet made a determination of finality under Rule 54(b). But Clark suggested very strongly, and at considerable length, that if such a determination were granted it would be an abuse of discretion..$^{23} \mathrm{He}$ had felt the same way in Pabellon but at that time would not have considered saying so in print. ${ }^{204}$ Likewise, Ferguson v. Bartels Brewing Co., ${ }^{205}$ in which actions against two business executives had been dismissed while the action against their alleged co-conspirator was still pending, echoed the prior case of United Artists Corp. v. Masterpiece Productions, Inc. ${ }^{266}$ Again, the district judge had not yet made a determination of finality. But Clark wrote his colleagues that such a determination would still not have saved the appeal. ${ }^{267}$ The per curiam opinion denying a petition for rehearing suggested that only the proposed amendment to Rule 54(b) providing for piecemeal review in multiple-party cases could do that. ${ }^{26 s}$

Clark's judicial record in Rule 54(b) cases thus showed him at his most reflective. He came to the bench with few views on the subject and was forced to work them out as cases arose, changing his mind several times. Having initially chosen a direction, he pursued

260. See Wright, Amendments to the Federal Rules, 7 VAND. L. REv. 521, 533-54 (1954).

261. 280 F.2d 755 (2d Cir. 1960).

262. See pp. 943-44 supra.

263. 280 F.2d at 757-59.

264. Memoranda in Pabellon v. Grace Linc, Inc., 191 F.2d 169 (2d Cir. 1951) (Junc $14 \& 26,1951$ ).

265. 284 F.2d 855 (2d Cir. 1960).

266. 221 F.2d 213 (2d Cir. 1955). See pp. $945-46$ supra.

267. Memorandum in Ferguson v. Bartels Brewing Co., 284 F.2d 855 (2d Cir. 1960)

(Nov. 4, 1960).

268. 284 F.2d at 857 . 
it as zealously as those he had settled on prior to his appointment. When changed conditions and strategic necessity obliged him to seek a different course, he found one and again defended it resolutely. Finally, when the controversy had ended, he felt frec to revert to his prior views.

\section{F. Scope of the Rules}

A final group of Judge Clark's decisions concerned the scope of the Federal Rules. In accord with his prior views, he was inclined to apply the Rules as widely as possible. From the time they were adopted, Clark campaigned as a rulemaker to extend the Rules to admiralty cases. ${ }^{269}$ This reform was finally enacted in 1966,200 three years after his death. Meanwhile, having warned that the judges might force the Federal Rules upon the admiralty bar if the rulemakers failed, ${ }^{271}$ Clark also pursued this goal in his opinions. A striking example is James Richardson of Sons, Ltd. v. Connors Marine Co., ${ }^{2 i 2}$ in which the respondent argued that the libel should have stated separately the allegations concerning each of 21 bargeloads of grain because the barges had been chartered by separate agreements. Clark acknowledged that admiralty rules still required a separate statement of each cause of action, but he disparaged this requirement by comparing it to the modern policy in Rule $10(\mathrm{~b})$, which calls for separate statements only when they facilitate presentation of the case. Clark contended that the admiralty rules should also be construed practically and that a separate statement serving no constructive purpose in this case was unnecessary. ${ }^{273}$

Clark also worked diligently for the merger of civil and admiralty actions, paralleling the merger of law and equity he had already accomplished. Noel v. Linea Aeropostal Venezolana ${ }^{274}$ illustrates his approach. The survivors of a victim of an airplane crash, having sued in admiralty for damages, brought another nearly identical suit at law to preserve their right to a jury trial. On appeal from a dismissal

269. Letter to Edmund Morgan (Apr. 6, 1953); Clark, The Proper Funclioning of the Supreme Court's Federal Rules Commiltee, 28 A.B.A.]. 521, 525 (1942) [hereinafter cited as Clark, Proper Functioning].

270. 2 Moore's Febral Practice đf 1.01 [4], at 112 (2d ed. 1975).

271. Letter to Roscoe Hupper (Dec. 17, 1941); Clark, Proper Functioning. supra note 269 , at 525 .

272. 14l F.2d 226 (2d Cir. 1944). Other examples are Star Brick Corp. v. Johnson, 262 F.2d 251 (2d Cir. 1959); Stathatos v. Arnold Bernstein S.S. Corp., 202 F.2d 525 (2d Cir. 1953).

273. 141 F.2d at 228 .

274. 318 F.2d 710 (2d Cir.), cert. denied, 355 U.S. 907 (1963). Other examples are McAfoos v. Canadian Pacific Steamships, Ltd., 243 F.2d 270 (2d Cir.), cert. denied, 355 U.S. 833 (1959); Civil v. Waterman S.S. Corp., 217 F.2d 94 (2d Cir. 1954). 
of the latter action, the parties focused on whether foreign law precluded a trial by jury. ${ }^{275}$ Clark, however, preferred to discuss the relationship between civil and admiralty suits, and he persuaded his reluctant colleagues on the panel to go along. ${ }^{276} \mathrm{His}$ opinion held that the civil action was properly dismissed because the original admiralty suit could embrace jury as well as nonjury claims. ${ }^{2 \pi}$ This was an important step toward merging the two systems. Not surprisingly, the plaintiffs complained in their petition for rehearing that the appeal had been decided on a ground never argued, nor even considered, by the parties. ${ }^{27 s}$

Occasionally, Clark conceded that admiralty practice differed from the Federal Rules, ${ }^{279}$ though in the most striking case his reasons were primarily tactical. Mercado $v$. United States, ${ }^{280}$ a personal injury action in admiralty by a seaman working for the federal government, concerned the admission at trial of a deposition submitted by the seaman. At first, Clark was determined to uphold admissibility, ${ }^{2 s 1}$ for that would have been the result under the Federal Rules, and, besides, a contrary decision meant depriving the injured seaman of his judgment. But in the end he not only decided that the deposition was inadmissible; ${ }^{252}$ he also held that several of the provisions of the Rules did not apply in admiralty and that transfer from admiralty to the civil side, where the Federal Rules would apply, was not permissible in seamen's injury suits against the federal government. ${ }^{283}$ The explanation for Clark's unusual behavior appears toward the end of the opinion:

We are the more constrained to this regrettable conclusion because a doubtful extension of the civil rules in admiralty may cause more confusion than a clean-cut decision demonstrating the need of revision. To our minds this case shows the desirability of making the civil rules directly applicable in admiralty . . . ${ }^{2 s t}$

275. 318 F.2d at 711 .

276. Memorandum in Noel v. Linca Acropostal Venezolana, 318 F.2d 710 (2d Cir. 1963) (May 2, 1963).

277. 318 F.2d at $\$ 11$.

278. Memorandum discussing Petition for Rehearing in Noel v. Linea Seropostal Venczolana, 318 F.2d 710 (2d Cir. 1963) (July 11, 1963).

279. E.g., Lo Buc v. United States, 178 F.2d 528, 531 (2d Cir. 1949) (Clark, J., dissenting); l'etrol Corp. v. Petroleum Heat \& Power Co., 162 F.2d 327, 330 (2d Cir. 1947). 280184 F.2d 24 (2d Cir. 1950).

281. Memorandum in Mercado v. United States, 184 F.2d 24 (2d Cir. 1950) (June 9, 1950 ).

282. 184 F.2d at 29.

283. Id. at 27-29. He stated that Rule 45(c)(1), providing for the subpoena of witneses within 100 miles of the place of trial, and Rule $26(d)(3)$, allowing the use of clepositions at trial when subpocnas vere unavailable, were not applicable in admiralty. 284. Id. at 29 . 
This all-or-nothing position embodied the strategy Clark had advocated 10 years earlier in an article entitled Dissatisfaction with Piecemeal Reform. ${ }^{285}$ Its rigidity was tempered by Clark's expectation that the deposition would be admissible upon retrial because of an intervening change in the rules of the Southern District of Nerw York. ${ }^{28 B}$

The other major issue of scope arose in diversity cases, where Erie Railroad v. Tompkins ${ }^{287}$ might require displacement of the Federal Rules by state law. Here again, Clark followed through on ideas developed earlier in his career. His first reaction to Erie was to warn against assuming ouster of the Rules. ${ }^{28 s}$ This warning soon ripened into a firm conviction, asserted in numerous articles and speeches, that the Federal Rules should apply except in unusual circumstances." ${ }^{2}$ ? Indeed, throughout the rest of his life he campaigned unceasingly for adoption of the Federal Rules in state court proceedings. 200

Clark rarely had occasion to express these views from the bench. The most important of the cases, Arrowsmith v. United Press International, ${ }^{201}$ was not decided until the last year of his life. The Second Circuit, sitting en banc, overruled a Clark precedent only three years old $^{292}$ and held that personal jurisdiction in an ordinary federal diversity suit could be based only on the law of the forum state. ${ }^{293}$ Clark, in angry dissent, persevered in his position that federal law might provide alternative grounds of jurisdiction. ${ }^{20 \pm}$ The Federal Rules were directly involved only to the extent that Rule $4(f)$ on the territorial limits of effective service might provide one of the alternative federal standards. But, as he often did, Clark heightened the controversy by arguing that the majority position foreshadowed the subjection of numerous other Federal Rules to the principle of Erie, a result he deplored. ${ }^{295}$

285. Clark, Dissatisfaction with Piecemeal Reform, 24 Jun. 121 (1940) [hcreinafter cited as Clark, Dissatisfaction].

286. Memorandum in Mercado v. United Statcs, 184 F.2d 24 (2d Cir. 1950) (Junc $10,1950)$.

287. 304 U.S. 64 (1938).

288. Pp. 920-21 supra.

289. E.g., Clark, Procedural Aspects of the New State Independence, 8 Geo. Wasu. L. REv. 1230 (1940); Clark, State Law in the Federal Courts: The Brooding Omnipresence of Erie v. Tompkins, 55 Y'ALE L.J. 267, 288-89 (1946) [hereinafter cited as Clark, State Law].

290. Clark, Proper Functioning, supra note 269, at 525; Clark, Dissatisfaction, supra note 285, at 122, See Wright \& Reasoner, Introdluction in Procedure: The HANDmaid OF JUSTICE 3 (C. WRIGHT \& H. REASONER eds. 1965).

291. 320 F.2d 219 (2d Cir. 1963).

292. Jaftex Corp. v. Randolph Mills, Inc., 282 F.2d 508 (2d Cir. 1960).

293. 320 F.2d at 230.

294. Id. at 239-41.

295. Id. at 242. See Riggs, Ferris \& Geer v. Lillibridgc, 316 F.2d 60 (2d Cir. 1963). For Clark's developing views on the application of Rule $60(\mathrm{~b})$ in bankruptcy pro. 


\section{Conclusions}

In accord with our initial speculations about judicial behavior, Judge Clark's votes in cases involving the Federal Rules were largely predictable. He came to the bench with resolute views on most matters covered by the Rules, and his work as a judge consisted of implementing them. He defended the validity of the Rules against challenges under the Constitution and the Rules Enabling Act, ${ }^{296}$ he brushed aside precedents that he thought construed the Rules incorrectly, and he even sought through his decisions to correct what he regarded as errors in the Rules themselves.

Clark's manner of expressing his views also befitted a judge who had explored the subject thoroughly and was determined to see his conclusions prevail. His opinions often dealt exhaustively with the procedural problems. He frequently spotted issues not evident to others, ruled on points that need not have been reached or were not in dispute, and espoused revisions in the law. When writing for the majority, he sought to curtail dissent; when in the minority, he insisted on having his own say. His efforts did not end with cases on which he sat. He would circulate memoranda on issues before they arose, urge en banc hearings when other panels contradicted his views, and privately rebuke the authors of errant opinions.

Clark's descriptions of himself reflected this tenacity. After a sharp exchange with Judge Learned Hand in 1944, he confessed: "I suppose we procedure guys get too excited when our babies appear maimed." 207 In a memorandum to the entire court in 1951, he explained his refusal to abide by certain precedents: "Since $I$ am so publicly committed to advocacy of procedural rules both simple and uniform, it is distressing to me, as well as confusing to others who read, to have to announce and follow procedural views $I$ oppose ...."20s And in a 1953 case memorandum, he asserted that Judge Frank "does not feel the compulsion which I as a Reporter to the

ceedings, see Delaware \& Hudson Co. v. New Yolk, N.H. \& H.R.R., 227 F.2d 291 (2d Cir.), cert. denied, 350 U.S. 987 (1955); Grand Union Equip. Co. v. Lippner, 167 F.2d 958 (2d Cir. 1948); Perlman v. 322 West 72d St. Co., 127 F.2d 716 (2d Cir. 1942); Kroell v. New York Ambassador, Inc, 108 F.2d 294 (2d Cir. 1939). For his views on the application of the Rules in cases in which the Government was a party, compare Bowles v. Bay of New York Coal \& Supply Corp., 152 F.2d 330 (2d Cir. 1945), with Sherwood v. United States, 112 F.2d 587 (2d Cir. 1940), rev'd, 312 U.S. 584 (1941). For Clark's overall assessment of the way in which the Rules were being effectuated, see Clark, Special Problems in Drafting and Implementing Procedural Codes and Rules, 3 VAND. L. REv. 493 (1950).

296. 28 U.S.C. $\$ 2072(1970)$.

297. M. Schick, supra notc 2, at $224 \mathrm{n} .8$ (quoting letter to Judge Learned Hand(Feb. 2, 1944)).

298. Id. at 105 (quoting memorandum to Second Circuit judges (Jan. 23, 1951)). 
Committee and as a teacher in the field do to make the rules workable."209

On the other hand, Clark's propensity to pursue his prior views in Federal Rules cases arose in part from causes peculiar to himself. Some of his votes may have been influenced by his nonprocedural sympathies. I have particularly in mind the pleading decisions in which he fostered civil liberties and antitrust enforcement and the skepticism of copyright claims that he showed in summary judgment cases like Arnstein v. Porter. ${ }^{300}$ Indeed, many of Clark's views on procedural issues themselves may have been influenced by his current political values as well as by prior scholarly commitments. Although not a declared New Dealer, Clark was at least a sympathizer of the cause. He was inclined to oppose big business ${ }^{301}$ and to see the federal government as the primary instrument of the public good. ${ }^{302}$ On the former ground, he might have tended to support procedural reforms, including simplified pleading and liberal joinder, which made litigation for both parties less expensive and less tricky. He also might have endorsed practices particularly favoring plaintiffs, such as leniency toward pleadings and liberal discovery. Moreover, his skepticism of states' rights might have disposed him against limiting federal jurisdiction or the application of federal procedural law. ${ }^{303}$

Even more clearly, Clark's conduct was influenced by his distinctive temperament. Descriptions by his associates consistently portray a person of decided views who never tired of seeking to effectuate them. Professor Fleming James noted that for a cause "he was not only always ready to do battle, but he was also dogged and perservering in his pursuit of it, far beyond the capacity or taste of most men." ${ }^{30 t}$ Similarly, Judge Harold Medina observed:

There may have been a touch of the spirit of compromise in his make-up, but I never noticed it.

-...

... [W]hen he got determined about something, he was going to keep harping on it and harping on it, and picking away and picking away until it was accomplished or the time to do anything was gone. ${ }^{30 s}$

299. Id. at 225 (quoting memorandum in Malman v. United States, 202 k.2d 483 (2d Cir. 1953) (Feb. 4, 1953)).

300. I54 F.2d 464 (2d Cir. 1946).

301. See M. Schick, supra note 2, at 248-49.

302. See ill. at 251; Clark, State Law, supra note 289, at 296.

303. See M. Schick, supra note 2, at 251.

304. Charles E. Clark, 73 YaLe L.J., Jan. 1964, at ix, x (faculty resolution authored by Professor Fleming James, Jr.).

305. Address by Judge Medina, Proceedings in Memoriam, Honorable Charles E. Clank, 328 F.2d 9, 12 (1964). 
And his good friend, Professor Fred Rodell, stated that "in a tough fight against long odds and rough opposition, it would be Charlie Clark I would rather have on my side." 306

Furthermore, Clark's record in Federal Rules cases did not consist simply of carrying out his prior views. First, there were certain points covered by the Rules, such as class actions and piecemeal appeals, to which Clark had contributed little as a draftsman and on which he came to the court without developed opinions. On these issues, Clark had to work out his stance as cases arose. He acknowledged as much in a lecture on the nerwly-adopted Rules shortly before he became a judge: "[T]here is one difficulty of my trying to stand up here and pass rather snap judgment on questions that certainly are going to be thoroughly litigated." 307 Some of the issues he resolved quickly, but others took him years to sort out, even with the help of his colleague Professor Moore, and in the meantime he often changed his mind. The prime example, of course, was his experience with Rule $54(\mathrm{~b})$.

Second, his own preferences sometimes conflicted with the Rules. Occasionally, as in the case of Rule 14 on third-party practice, he felt that the Rules went too far toward reform; more typically, he believed that they did not go far enough. His tendency in these cases was to adhere to his own views rather than to the Rules. Indeed, shortly after being appointed judge, he joked to a former colleague on the Advisory Committee: "In fact, I suppose I can try to correct some of the mistakes which I think the Committee may have made, if that is according to the rules of the game, and isn't it?" $30 \mathrm{~s}$ Yet, at times Clark subordinated his own preferences to superior authority-the language or legislative history of a Rule or an interpretation by the Supreme Court. The most striking example is Vibra Brush Corp. v. Schaffer, ${ }^{319}$ in which he suppressed his opposition to strict substitution requirements.

Third, even when Clark's personal views coincided with the Rules, he had choices to make. A man of affairs, he was sensitive to strategic political considerations, and sometimes these overcame his procedural preferences. He declined to write at length on subjects dear to him or even kept silent altogether, for fear of creating trouble. He went so far as to speak somewhat against his own views, as in

306. Rodell, For Charles E. Clark: A Brief and Belated, But Fond Farewell, 65 Couvar. L. REV. 1323, 1328 (1965).

307. 1938 Cleveland Proceedings, supra note 10, at 254.

308. Letter to George Donworth, Oct. 26, 1939.

309. 256 F.2d 681 (2d Cir. 1958). See p. 937 supra. 
his stern disparagement of "notice pleading," 310 to avert worse dangers. He even cast votes inconsistent with his personal preferences. One notable instance was his occasional refusal to apply the Rules piecemeal in admiralty cases in order to highlight the need for wholesale reform. ${ }^{311}$

There was an even more extraneous influence which perplexed Clark in cases involving the Federal Rules. Although he heartily endorsed Judge Frank's appointment to the Second Circuit, he gradually came, I believe, to dislike Frank. It is natural to cite their many disagreements on procedural issues-especially summary judgments and interlocutory appeals-as a cause of the tension between them. ${ }^{312}$ But I would suggest that the reverse may also have been true-that animosity affected Clark's views on those issues. I find it difficult to explain the extreme vehemence with which he endorsed expanded appealability under amended Rule 54(b), for example, without allowing for his personal desire to thwart Frank.

Most revealing of all, there were subjects on which Clark felt obliged to rethink his own well-developed views as new procedural considerations appeared. This might have been expected on questions of means, such as how merger might best be served in cases with both legal and equitable claims. Yet Clark was sometimes forced to reassess his ends, faced by newly perceived conflicts among basic values. The most notable example was his decision to relent on piecemeal appeals, in part in order to hold down the cost of litigating the issue. ${ }^{313}$ In such cases Clark had to make difficult choices, and there would have been no sure way of predicting in advance what his choices might be.

Professor Lon Fuller once wisely wrote:

[T] he judicial office can bring to expression both capacities for problem-solving and individual differences in fundamental values. One may, indeed, distinguish in the judicial process two aspects, the one consisting of what may be called signpost-setting, the other of constructing roadways to the destinations indicated by the signs. Just as there are legislators who are magnificent on the floor and weak in committee, so there are judges who are very adept in setting signposts but less effective in road construction. One sometimes has the uncomfortable feeling that these are the favorites of the predictors [of judicial behavior]. Certainly such judges offer more tractable material for their researches. ${ }^{314}$

310. P. 925 supra.

311. Pp. 949-50 supra.

312. See M. Schick, supra note 2, at 245.

313. See p. 943 supra.

314. Fuller, An Afterword: Science and the Judicial Process, 79 HARv. L. REv. 1604, 1620 (1966). 
Judge Clark and the Federal Rules

Clark was indeed "magnificent on the floor," a tenacious battler for causes in which he believed. His conduct as a judge in cases involving the Federal Rules was correspondingly predictable. But his work as Reporter showed that he was also strong "in committee." ${ }_{15}$ He did not lose this capacity when he became a judge. He remained intelligent enough by far to recognize hard problems and sufficiently scrupulous to seek to solve rather than evade them. For this reason his judicial behavior can never be reduced to a simple formula.

315. See M. ScHick, supra note 2, at 31 (quoting remarks of Henry Chandler). 


\section{The Yale Law Journal}

Volume 85, Number 7, June 1976

\author{
JoHN W. SPIEgel \\ Editor-in-Chief \\ Edward R. Muller \\ Managing Editor \\ Marc L. Brown \\ JOSEPH ISENBERGH \\ EDWARD D. KLEINBard \\ GLEN A. REED \\ Article \& Book Revicw \\ Editors
}

\author{
RUTH N. GLushieN \\ Executive Editor \\ Madeleine A. Kleiner \\ Note \& Project Editor \\ WALTER P. LOUGHLIN \\ Thomas H. MILCH \\ GLENN M. REITER \\ Michael E. Robinson \\ Jefrrey L. Schulte \\ Note Editors
}

T. Alexander Aleinikoff Jerome Davis LON S. BABBY GEORGe M. BEAL II ToM A. BERNSTEIN Donald N. BersofF J. BRUCE BoIsture Daniel H. BookIN Charles G. Buschitan Kenneth S. Canfield Ralph C. Gavanagh BENJAMIN I. COHEN Business Manager KEITH P. ELLISON Peter Feuerle ROBERT T. HAAR Carl W. Herstein Mark D. Hoffer Peter R. Jarvis RichaRd A. JOHNSON Peter T. Joseph
Simeon M. Kriesberg Albert G. Lauber, JR. Paul C. Lembesis Carlos E. Méndez-Peñate Robert C. Post Walter F. Pratt Deborah L. RHODE STEPHEN E. Roth JoNathan W. STILL Seth P. WAXMaAN ROBERT N. WEINER

Secretaries to the Editors M. Olive Butrerfield, Pamela Willmott

\section{Student Contributors to This Issue}

Albert G. Lauber, Jr., Executory Labor Contracts and Municipal Bankruptcy

Jerome Davis, Disbarment in the Federal Courts 